\title{
Subaqueous conglomerates above pre-LGM basal till: Another element of the 'classic' interglacial mountain-flank succession [Hötting Breccia Auct.] north of Innsbruck, Austria
}

\author{
Diethard Sanders, Sabine Pernreiter
}

How to cite:

Sanders, D. \& Pernreiter, S. (2016): Subaqueous conglomerates above pre-LGM basal till: Another element of the 'classic' interglacial mountain-flank succession (Hötting Breccia Auct.) north of Innsbruck, Austria. - E\&G Quaternary Science Journal, 65 (1): 4-23. DOI: $10.3285 /$ eg.65.1.01

Abstract:

The "Hötting Breccia" near Innsbruck is a classic interglacial mountain-flank succession mainly comprising lithified alluvial fans and scree slopes. Directly NW of Innsbruck, a pre-LGM (Riss?) basal till >20 $\mathrm{m}$ in thickness overlies a plucked rock surface that records eastward ice flow. The till is dominated by clasts of carbonate rocks from the Northern Calcareous Alps; index clasts of the LGM ice stream are absent. The basal till is overlain by a package of conglomerate nearly $1 \mathrm{~km}$ in preserved lateral extent that dip at $20-30^{\circ}$ South and show the same clast spectrum as the underlying till. The conglomerate - hitherto assigned to the Hötting Breccia - accumulated from fan deltas and/or scree slopes shed into a standing water body; it is overlain by younger, unlithified LGM to Holocene deposits.

We suggest the following scenario: During decay of the ice stream that formed the basal till, the conglomerate package was deposited by paraglacial reworking of till into a lake or ice-marginal lake. The alluvial fans of the Hötting Breccia accumulated independently from the conglomerate package, and from a distinct alluvial-fan system. The age relation of the till/conglomerate package to the main part of the Hötting Breccia is unclear. Our results demonstrate that the rocks hitherto summarized as Hötting Breccia represent a compound of lithosomes of different origins and ages.

Subaquatische Konglomerate auf vor-letztglazialem Till: Ein weiterer Baustein der ,klassischen` interglazialen Bergflanken-Abfolge [Höttinger Brekzie Auct.] nördlich von Innsbruck, Österreich

Kurzfassung: $\quad$ Die „Höttinger Brekzie“ bei Innsbruck - eine klassische interglaziale Sedimentabfolge entlang einer Bergflanke - besteht vorwiegend aus verfestigten subaerischen Schuttfächern und Haldenhängen.

Am NW-Rand Innsbrucks lagert eine bis >20 m dicke prä-LGM Grundmoräne (Riss?) auf einer Schlifffläche auf Fels, die ostgerichtete Eisbewegung anzeigt. Die Grundmoräne ist von Karbonatgesteinen der Nördlichen Kalkalpen dominiert; Leitgeschiebe des LGM-Eisstroms fehlen. Die Grundmoräne wird von einem Konglomerat überlagert, dessen Schichtung 20-30 Süd fällt und dessen Klastenbestand dem des liegenden Tills entspricht. Das Konglomerat - bisher als Teil der Höttinger Brekzie geführt wurde von einem Fächerdelta oder einem Haldenhang in einen See geschüttet; es wird von unverfestigten Sedimenten des LGM bis Holozän überlagert.

Folgendes Szenario wird vorgeschlagen: Während oder nach Zerfall des Eisstroms, der die Grundmoräne gebildet hatte, wurde durch Umlagerung des Tills in einen (Eisrand?-) See die Konglomerat-Abfolge geschüttet. Die subaerischen Schuttfächer der Höttinger Brekzie bauten sich unabhängig vom Konglomerat von einem eigenständigen Schuttfächer-System auf. Die Altersbeziehung zwischen dem Hauptteil der Höttinger Brekzie und der Grundmoräne/Konglomerat-Abfolge ist unklar. Diese Arbeit zeigt erneut, dass die Abfolge, die bisher kollektiv als Höttinger Brekzie zusammengefasst wurde, aus Sedimentkörpern verschiedener Bildung und Alter besteht.

Keywords: $\quad$ Alps, Quaternary, interglacial, Hötting Breccia, till, conglomerate, index clasts

Addresses of authors: D. Sanders*, S. Pernreiter, Institute of Geology, University of Innsbruck, Innrain 52, A-6020 Innsbruck, Austria/EU, E-Mail: Diethard.G.Sanders@uibk.ac.at; *corresponding author

\section{Introduction}

The mountain flank north of the city of Innsbruck is partly covered by a lithified, coarse-clastic slope succession that for centuries provided building stones for masonry (SIEGL \& FAHLENBÖcK 2012). This succession, the so-called Hötting Breccia (HB), accumulated mainly from alluvial fans and scree slopes (Fig. 1) (SANDERS \& SPÖTL 2014, and references therein). Because the HB is sandwiched between underlying pre-last Glacial lodgement till and overlying basal till of the Last Glacial Maximum (LGM) it provided one of the first proofs of repeated Pleistocene glaciations separated by interglacials (Fig. 2) (e.g. BöHм 1884, BLAAs 1885, 1889, PencK 1885, 1887, LePsius 1913, AmpfERER 1914). In consequence, the $\mathrm{HB}$ was subject to numerous investigations with different perspectives (see, e.g. literature lists in PENCK 1921 and PAsChinger 1950). A long-standing dispute is whether all of the deposits traditionally assigned to 


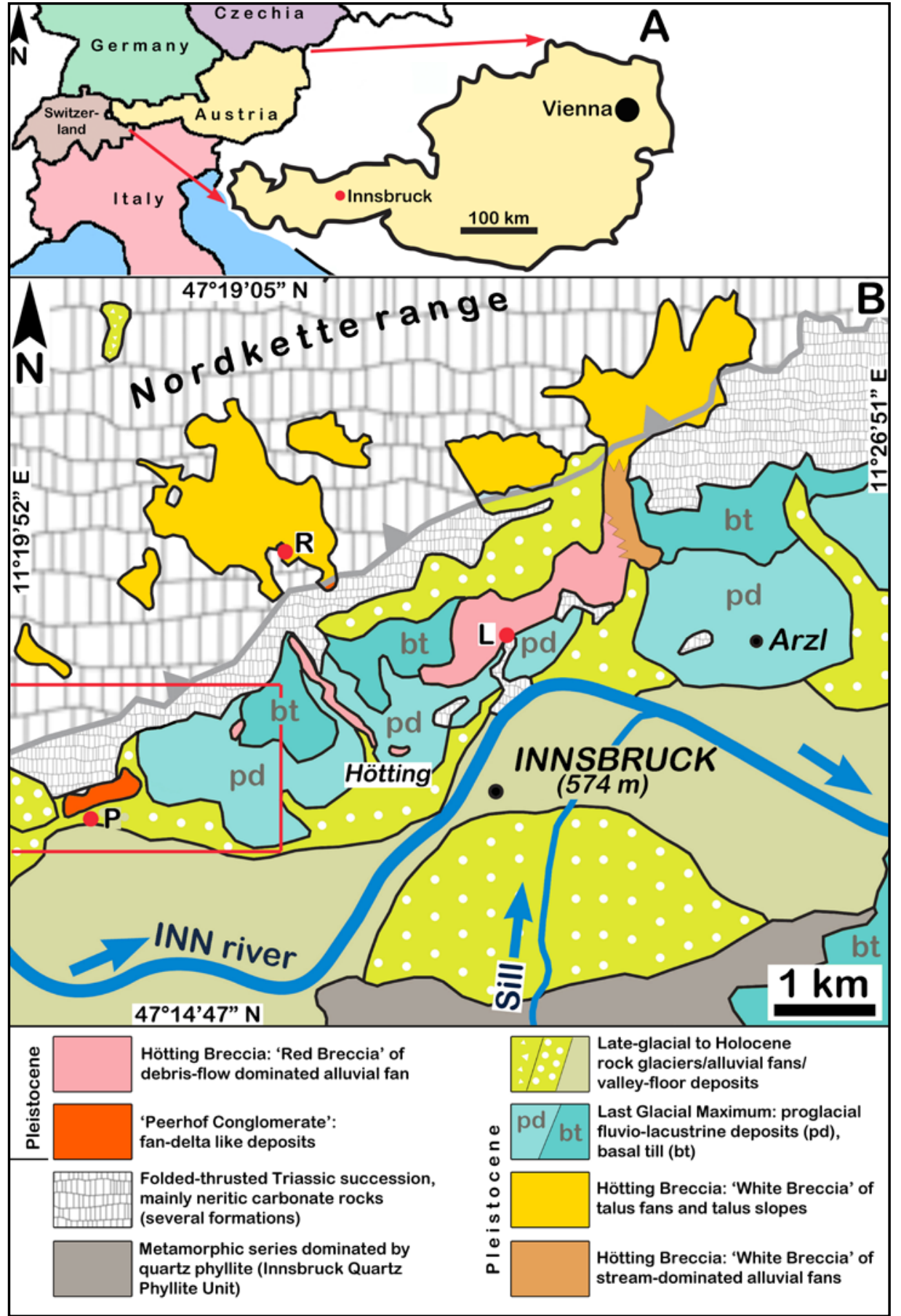

Fig. 1: A. Position of Innsbruck in Europe. B. Simplified geological map of: (a) deposits traditionally assigned to the Hötting Breccia, and (b) the 'Peerhof Conglomerate' (PC, hitherto assigned to the Hötting Breccia). $L=$ Lepsius adit or Geologenstollen (see also Fig. 2); $R=$ location Rossfall-Lahner (see also Fig. 2); $P=$ location Peerhof, the type area of the $P C$ described herein. Red rectangle: area considered in detail for the present paper. Abb. 1: A. Lage von Innsbruck in Europa. $B$. Vereinfachte geologische Karte von: (a) den Ablagerungen, die traditionell zur Höttinger Brekzie gezählt wurden, und (b) dem ,Peerhof-Konglomerat' (bislang zur Höttinger Brekzie gestellt). $L=$ Lepsius-Stollen oder Geologenstollen (siehe auch Abb. 2); $P$ = Örtlichkeit Peerhof, das Typ-Areal für das Peerhof-Konglomerat, das in dieser Arbeit beschrieben wird. Rotes Rechteck: Hierin betrachtetes Gebiet. the $\mathrm{HB}$ represent a single cycle of accumulation - a view advocated, for instance, by Penck and Blaas - or whether it consists of different sediment bodies separated by surfaces of intermittent erosion or nondeposition - a possibility suggested by Lepsius and Ampferer, and supported by recent investigations (cf. SANDERS \& OSTERMANN 2006, SANDERS 2008, 2010).

Along the toe of the mountain flank near the present northwestern fringe of Innsbruck city, pre-LGM till is present that is overlain by a package of conglomerates with a preserved lateral extent of nearly $1 \mathrm{~km}$ (Peerhof Conglomerate in Fig. 1). Both the till and the conglomerates later fell forgotten, perhaps because they are mainly exposed along the flanks of triangular slope facets that tend to conceal the true extent of the deposits. Triangular slope facets (BüDEL 1982) or flatirons (Koons 1955) can form along the toe of slopes when the rate of erosional incision exceeds the rate of accumulation over a longer interval of time (e.g. GutIÉRREZ, GUTIÉRREZ \& DESIR 2006).

BLAAS (1885, p. 23) was first to mention the till and the conglomerates and - as AMPFERER (1904, p. 115) did later - placed them subjacent to deposits related to the LGM. PENCK (1921) was the last who showed till and conglomerates in a geological map (scale 1:30,000); he also correlated the till beneath the conglomerates with a well-known pre-LGM lodgement till traditionally referred to as Liegendmoräne as best-exposed in an artificial adit farther east (see Fig. 1, 2) (cf. LePsius 1913, AmpFERER 1914). Because the conglomerates overlie pre-LGM till, PENCK (1921) mapped them with the same colour and same labeling than the rest of the Hötting Breccia (see also BlaAs 1891). There is no physical continuity, however, from unequivocal Hötting 


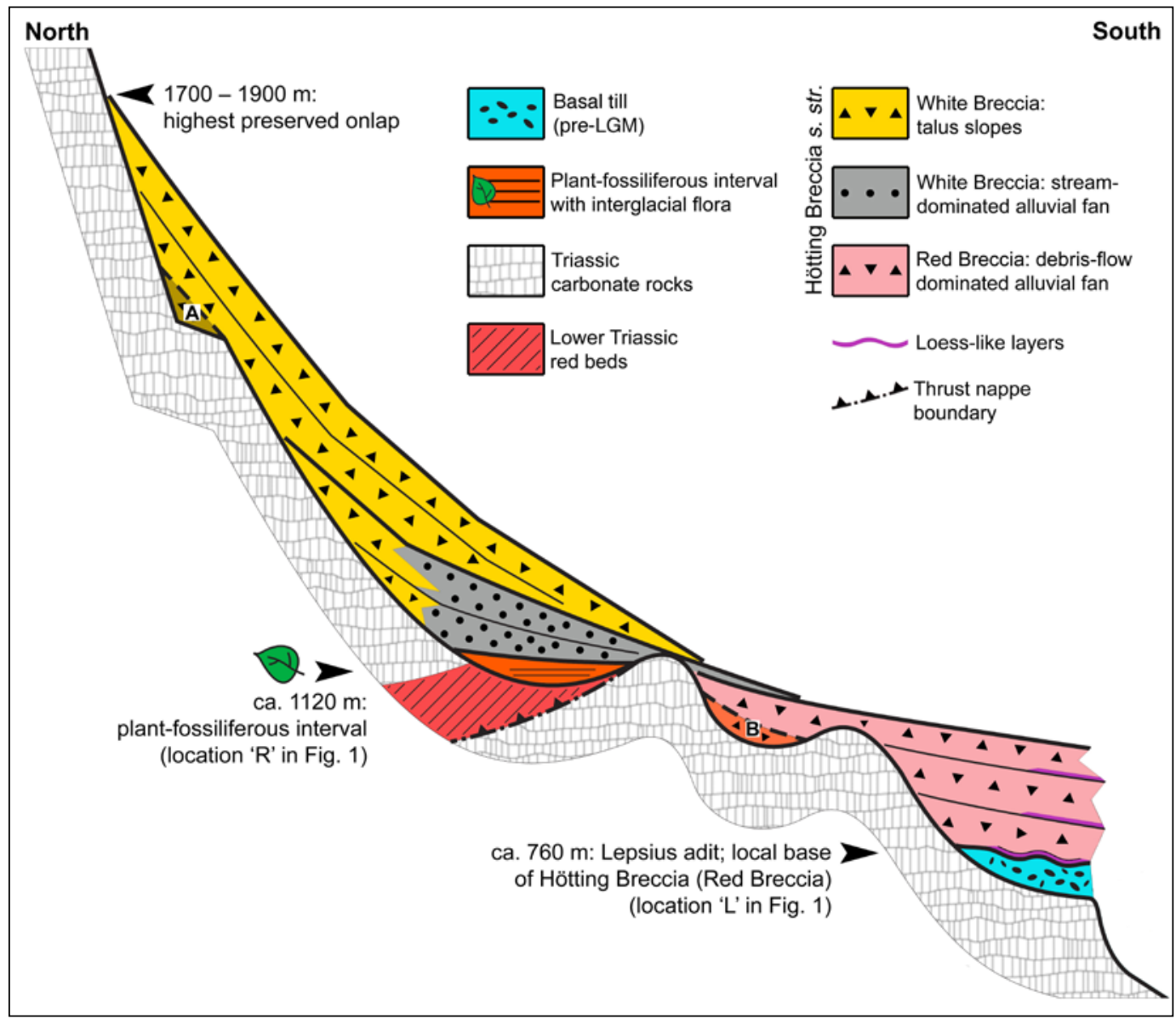

Fig. 2: Schematic, vertically exaggerated section summarizing the features of the Hötting Breccia in the central and western outcrop sector (cf. Fig. 1; modified from SANDERS \& SPÖTL 2014). A, B: Hypothetical position of erosional remnants of older slope succession.

Abb. 2: Schematischer, übersteilter Schnitt Höttinger Brekzie im zentralen und westlichen Abschnitt der Aufschlüsse (vgl. Abb. 1; verändert nach SANDERS \& SPÖTL 2014). A, B: Hypothetische Lage von Erosionsresten einer älteren HangAblagerung.

Breccia in the East with the till/conglomerate package farther west. As outlined below, several problems arise when trying to correlate, or even to equate, the till/conglomerate package with the Hötting Breccia. Herein, the basal till and the conglomerate package are described for the first time in detail. We interpret the conglomerates as subaqueous deposits of a fan delta or a subaqueous scree slope supplied from paraglacial reworking of the till, and that perhaps was shed into an ice-marginal lake. Our observations further underscore that the mountain-flank succession previously summarized as "Hötting Breccia" in fact consists of lithosomes of different origins and, probably, also of different ages.

\section{Setting}

The Nordkette mountain range north of Innsbruck is the southernmost crest of the Northern Calcareous Alps (NCA) that consist mainly of folded and thrusted Triassic carbonate rocks (Fig. 1). The Nordkette consists of two cover-thrust nappes dominated by Triassic limestones and dolostones (Fig. 1, 2, Tab. 1). In the basal part of the upper nappe, over much of the lateral extent of the Nordkette, Lower Triassic red beds (claystones to quartzites) are exposed. These red beds supplied, and still supply, pink- to dark red-coloured clasts to Quaternary deposits along the mountain flank (Fig. 2). In the present study area - located along the lower slope of the western Nordkette range - the rock substrate consists mainly of limestones and dolostones of Middle to Late Triassic age (Fig. 1). The red beds, in contrast, pinch out structurally approximately $1 \mathrm{~km}$ east of the area of interest.
The Hötting Breccia is traditionally subdivided into (see Fig. 1, 2): (1) the 'Red Breccia', with a part of the lithoclast spectrum and of the fine-grained matrix derived from the Lower Triassic red beds. The Red Breccia accumulated from alluvial fans characterized by: (a) subaerial cohesive debris flows, and (b) water-laid breccias to conglobreccias of torrential floods. The Red Breccia is locally intercalated with intervals up to $\sim 20 \mathrm{~cm}$ thick of polymictic silt to fine sand of aeolian origin. (2) The 'White Breccia', in turn, consists of carbonate-rock clasts only and, in some facies, of a lightgrey to whitish matrix of lime mudstone. The upper part of the White Breccia consists of large fossil talus slopes. The lower part of the White Breccia accumulated from streamdominated alluvial fans; the latter are confined to the easternmost sector of outcrop (see Fig. 1). Mapped facies relations and depositional geometries indicate that the deposition of Red and White Breccia, respectively, at least in part overlapped in time (see SANDERS 2010 and SANDERS $\&$ SPÖTL 2014 for further description).

The HB is locally underlain by a basal till (Liegendmoräne) of a glaciation that pre-dated the LGM (Fig. 2). The most prominent exposure of this till is provided by 'Lepsius adit', a short tunnel excavated to investigate the stratigraphic relation between the till and the $\mathrm{HB}$ (location $\mathrm{L}$ in Fig. 1) (Lepsius 1913, AmpFerer 1914). At this adit, the till shows an erosional relief that is onlapped and overlain by the HB (PENCK 1921); in addition, a tree embedded in upright position by the deposits of the HB shows that the till surface was vegetated (AMPFERER 1914, PENCK 1921). This also indicates that the accumulation of the Red Breccia started well-after disappearance of glacial ice and poten- 
Tab. 1: Stratigraphic units of the Northern Calcareous Alps relevant for the present paper. For summaric descriptions and interpretations of units see, e.g., MANDL (1999). Not all of these units are of formal lithostratigraphic status (cf. PILLER et al. 2004).

Tab. 1: Relevante stratigraphische Einheiten der Nördlichen Kalkalpen. Für zusammenfassende Beschreibungen und Deutungen der Einheiten siehe z.B. MANDL (1999). Nicht alle der gelisteten Einheiten haben formalen lithostratigraphischen Rang (vgl. PILLER et al. 2004).

\begin{tabular}{|c|c|c|c|c|}
\hline \multicolumn{2}{|l|}{ Stratigraphic unit } & Range & Characteristic lithologies & Interpretation \\
\hline \multicolumn{2}{|c|}{$\begin{array}{l}\text { Alpiner Buntsandstein to lower Werfen Formation } \\
\text { pro parte } \\
=\text { „Lower Triassic red beds“ in text }\end{array}$} & Lower Triassic & $\begin{array}{l}\text { Dark red claystones to } \\
\text { siltstones, fine- to medi- } \\
\text { um-grained quartzites with } \\
\text { haematite }\end{array}$ & $\begin{array}{l}\text { Distal alluvial to marginal- } \\
\text { marine deposits of semi-arid } \\
\text { environment. Red colour } \\
\text { results from disperse haem- } \\
\text { atite and haematitic cement }\end{array}$ \\
\hline \multicolumn{2}{|l|}{ Reichenhall Formation } & Middle Triassic pro parte & $\begin{array}{l}\text { Cellular dolostones, organ- } \\
\text { ic-rich dolostones-lime- } \\
\text { stones, marly limestones- } \\
\text { dolostones, marls, sulphate } \\
\text { evaporites }\end{array}$ & $\begin{array}{l}\text { Marine, restricted shallow } \\
\text { subtidal to supratidal de- } \\
\text { position in arid to semi-arid } \\
\text { climate }\end{array}$ \\
\hline \multirow{4}{*}{ "Alpine Muschelkalk Group” } & Virgloria Formation & Middle Triassic pro parte & $\begin{array}{l}\text { Stylo-nodular burrow- } \\
\text { mottled lime mudst to wkst, } \\
\text { bioclastic wkst to pkst; } \\
\text { locally dolomitized }\end{array}$ & $\begin{array}{l}\text { Subtidal deposition on the } \\
\text { inner to middle part of a } \\
\text { wide, ramp-like carbonate } \\
\text { shelf }\end{array}$ \\
\hline & Steinalm Formation & $\begin{array}{l}\text { Upper Anisian Middle } \\
\text { Triassic pro parte }\end{array}$ & $\begin{array}{l}\text { Bioclastic limestones of } \\
\text { dasycladaleans and cri- } \\
\text { noids; locally dolomitized }\end{array}$ & $\begin{array}{l}\text { Subtidal sand bodies of } \\
\text { fragments from calcareous } \\
\text { algae and crinoids }\end{array}$ \\
\hline & Reifling Formation & Middle Triassic pro parte & $\begin{array}{l}\text { Nodular to evenly-bedded, } \\
\text { locally cherty lime mudsts } \\
\text { to bioclastic pksts; locally } \\
\text { dolomitized }\end{array}$ & $\begin{array}{l}\text { Neritic deposition on a } \\
\text { carbonate shelf undergoing } \\
\text { tectonically-induced dif- } \\
\text { ferentiation into platforms } \\
\text { and basins }\end{array}$ \\
\hline & $\begin{array}{l}\text { Schusterberg } \\
\text { Limestone }\end{array}$ & $\begin{array}{l}\text { within Reifling } \\
\text { Formation }\end{array}$ & $\begin{array}{l}\text { Light-red to pink, nodular } \\
\text { cherty lime mudsts to } \\
\text { bioclastic wksts with radio- } \\
\text { larians and ammonites }\end{array}$ & $\begin{array}{l}\text { Deep neritic deposition } \\
\text { associated with relative } \\
\text { sea-level rise on a carbon- } \\
\text { ate shelf }\end{array}$ \\
\hline \multicolumn{2}{|l|}{ Partnach Formation } & $\begin{array}{l}\text { Middle to Upper Triassic } \\
\text { pro parte }\end{array}$ & $\begin{array}{l}\text { Shales with intercalated } \\
\text { beds/bedsets of marly to } \\
\text { pure, dark grey to blackish } \\
\text { lime mudst to shallow- } \\
\text { water bioclastic pksts }\end{array}$ & $\begin{array}{l}\text { Basinal terrigenous clastics } \\
\text { with intercalated calcitur- } \\
\text { bidites derived from con- } \\
\text { temporaneous carbonate } \\
\text { platform } \\
\text { Basinal equivalent to } \\
\text { Reifling Fm and Wetterstein } \\
\text { limestone }\end{array}$ \\
\hline \multicolumn{2}{|l|}{ Wetterstein Limestone } & $\begin{array}{l}\text { Middle to Upper Triassic } \\
\text { pro parte }\end{array}$ & $\begin{array}{l}\text { [1] limestones of reefal, } \\
\text { peri-reefal and lagoonal } \\
\text { environments } \\
\text { [2] fenestral lime mudst, } \\
\text { tepees, laminated do- } \\
\text { lostones, etc. of inter- to } \\
\text { supratidal environments }\end{array}$ & $\begin{array}{l}{[1]+[2] \text { : deposition from }} \\
\text { fore-reef to lagoonal and } \\
\text { tidal-flat environments of } \\
\text { shallow-water carbonate } \\
\text { platform }\end{array}$ \\
\hline \multicolumn{2}{|l|}{ Northern Alpine Raibl beds } & Upper Triassic pro parte & $\begin{array}{l}\text { Variegated, mixed silici- } \\
\text { clastic-carbonate succes- } \\
\text { sion of shales, bioclastic } \\
\text { and fenestral limestones, } \\
\text { dolostones, cellular dolos- } \\
\text { tones }\end{array}$ & $\begin{array}{l}\text { Mixed siliciclastic-carbon- } \\
\text { ate-evaporitic deposition in } \\
\text { neritic to peritidal environ- } \\
\text { ments } \\
\text { Unit contains oncolite beds } \\
\text { in its basal part }\end{array}$ \\
\hline \multicolumn{2}{|l|}{ Hauptdolomit unit } & Upper Triassic pro parte & $\begin{array}{l}\text { Coarse crystalline, thick- to } \\
\text { very thick-bedded, brown- } \\
\text { weathering dolostones and } \\
\text { fenestral-stromatolithic } \\
\text { dolostones }\end{array}$ & $\begin{array}{l}\text { Deposition in lagoonal to } \\
\text { peritidal sector of a large at- } \\
\text { tached carbonate platform }\end{array}$ \\
\hline
\end{tabular}

tial ice-marginal lakes, when the Inn valley was already reoccupied by at least sparse vegetation. Plant fossils within the Red Breccia suggest a relatively cool climate while the alluvial fans and at least the lower part of the mountain flank were vegetated (MurR 1926). A cool and dry climate is further suggested by layers of windblown silt (loess-like layers) intercalated into the Red Breccia (Fig. 2) (LADURNER 1956, ОвојеS 2003). 
On the Hungerburg terrace directly north of Innsbruck, the number of intervals of glacial tills still is unclear. PENCK (1921) had distinguished three till levels: (a) the lowest dubbed Liegendmoräne sandwiched between Triassic bedrock and the $\mathrm{HB}$, and assigned to the Mindel glaciation, (b) the Sockelmoräne till, assigned to the Riss glacial, and (c) the Hangendmoräne till of the LGM. Based on this subdivision of tills, PENCK (1921) considered the Hötting Breccia as a Mindel-Riss interglacial deposit (corresponding to the Holstein of northern Germany). Unfortunately, the Sockelmoräne was mainly observed in ephemeral outcrops upon construction of the road from Innsbruck up to Hungerburg (KATSCHTHALER 1930). AmpFerer (1936) recognized that the southern fringe of the HB is locally downthrown by gravitational mass movements, and concluded that the Sockelmoräne and Hangendmoräne tills would pertain to a single level. In consequence, he advocated a Riss-Würm interglacial age of the HB (corresponding to the Eem of northern Germany). Drillings for air raid shelters seemed to confirm this conclusion (AMPFERER 1946).

At $\sim 1140 \mathrm{~m}$ a.s.l., the White Breccia is underlain by a succession ('Rossfall-Lahner interval') that hosts a diversified fossil flora (location R in Fig. 1, 2) (e.g., WettsteIn 1892, MURR 1926). The fossil plants indicate a warm-interglacial climate of similar temperature and humidity as today, with mountain slopes vegetated at least to a similar extent as nowadays (MURR 1926). The most fossiliferous beds accumulated in a small lake, or ephemeral lakes/ponds, within a larger setting of a stream-dominated alluvial fan (SANDERS \& OSTERMANN 2006). Based on the palaeoflora, MURR (1926) advocated a Riss-Würm interglacial age of the Hötting Breccia.
As mentioned, most authors after PENCK (1921) assumed that the Hötting Breccia is of Riss-Würm interglacial age; until spring 2014, this preliminary age assignment was consistent with radiometric ages (SANDERS \& SPÖTL 2014). New $\mathrm{U} / \mathrm{Th}$ ages of speleothem flowstones along fractures in the Red Breccia, however, indicate that the breccia was lithified and fractured already at $167 \pm 2 \mathrm{ka}$ (SpÖTL, MANGINI $d$ Cheng 2014). The HB, or part of it, thus accumulated during an older interglacial.

In the $\mathrm{HB}$, two types of intraclasts were identified: (1) Single-cycle intraclasts of (a) scree-slope facies, (b) alluvial-fan facies (White Breccia, Red Breccia), and (c) conglobreccias to conglomerates rich in metamorphic rock fragments, and supported by a matrix of yellow lime mudstone. In some intraclasts, tilted geopetals of laminated lime mudstone, as well as truncation of and dissolution pits into rock fragments along the outer intraclast surface, indicate that these were already lithified prior to transportation. (2) Multi-cycle intraclasts comprise matrix-supported conglobreccias to conglomerates, plus single-cycle intraclasts (White or Red Breccia). These intraclasts indicate that the $\mathrm{HB}$ is a compound of unconformity-bounded rock bodies (SAnders 2008, 2010). During the LGM, the HB was subject to further glacial erosion, and became onlapped and overlain by a diversified suite mainly of aggrading alluvial fans supplied from local catchments, of proglacial fluviolacustrine deposits, and the Hangendmoräne till (e.g. PENCK 1921, KATSCHTHALER 1930).

Downstream of the outlet of the right-hand tributary Oetztaler Ache into the Inn river $\sim 40 \mathrm{~km}$ west of Innsbruck, the Inn ice stream of the LGM can be identified by a suite

Tab. 2: Clast spectrum considered as typical of the Inn ice stream (downstream of Oetz valley, see text) of the Last Glacial Maximum.

Tab. 2: Typisches Klastenspektrum des Inn-Eisstroms (abwärts des Oetztals, siehe Text) des Letzten Glazialen Maximums.

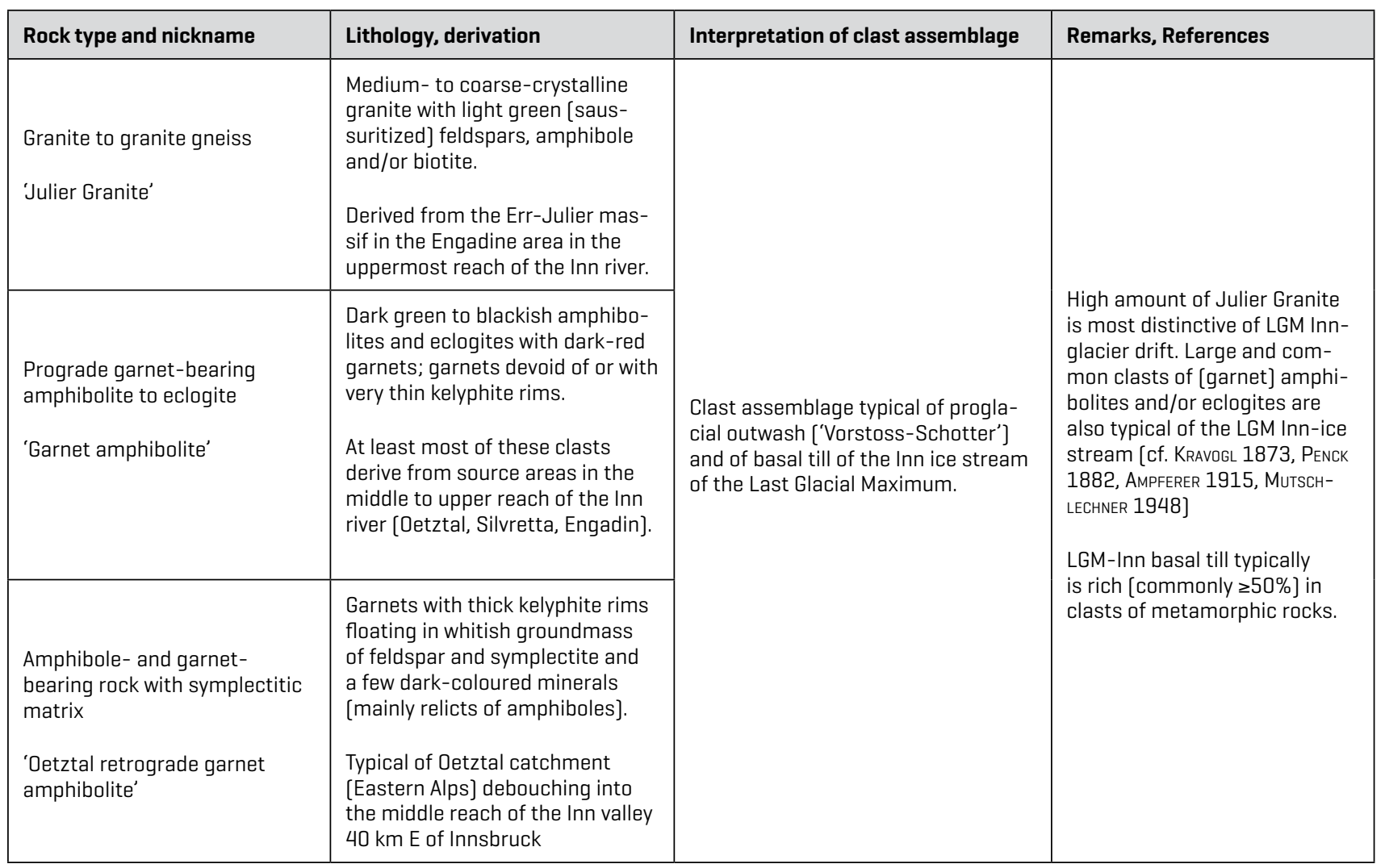






Fig. 3: A. Catchments of: (1) Sulzenbach stream, (2) Gufeltal ravine, and (3) Höttinger Graben (the latter not shown completely). The slope between Kranebitten gorge and Höttinger Graben shows two triangular slope facets (tsf). Outcrops of Northern Alpine Raibl beds with oncolites used as index clasts for the present study (cf. Tab. 1) shown in orange. Hillshade from http://tiris.tyrol.at.

B. Map with most relevant Quaternary deposits mentioned herein. The PC is sandwiched between a pre-LGM till and overlying till of the LGM. Red Hötting Breccia (cf. Fig. 2) starts $\sim 900 \mathrm{~m}$ east of the PC. White rectangle: area of Fig. 4. Hillshade from http://tiris.tyrol.at.

Abb 3: A. Einzugsgebiete (1) der Kranebitter Klamm, (2) der Gufeltal-Rinne, und (3) des Höttinger Grabens (letzteres nicht gänzlich). Die Bergflanke zwischen Höttinger Graben und Kranebitter Klamm zeigt zwei dreieckige Hangfacetten (tsf). Orange: Aufschlüsse von Nordalpinen Raibler Schichten mit Onkoliten, die in dieser Studie als Leitgeschiebe dienten (vgl. Tab. 1). Hillshade von http://tiris.tyrol.at.

B. Karte hierin erwähnten wichtigsten quartären Ablagerungen. Das Peerhof-Konglomerat liegt zwischen einem vor-letztglazialen Till und einem hangenden Till des LGM. Rote Höttinger Brekzie (vgl. Abb. 2) setzt $900 \mathrm{~m}$ östlich des Peerhof-Konglomerats ein. Weißes Rechteck: Ausschnitt in Abb. 4. Hillshade von http://tiris.tyrol.at. 
of three metamorphic rock types (Tab. 2). In the area of Innsbruck, deposits related to the LGM are preserved in large terraces and slope facets fringing the valley. In a very generalized fashion, and with some variation depending on location, from bottom to top the terraces or slope facets mainly consist of: (i) fluvio-lacustrine deposits and/or of proglacial outwash, topped by (ii) basal till of the LGM Inn ice stream (Fig. 1) (e.g. Ampferer 1908, Heissel 1954, Fliri et al. 1970). Along its southern outcrop limit, the Red Breccia is steeply truncated and strikes out into air. At Hungerburg terrace, the very steep to subvertical truncation surface is cut into both the Triassic bedrock and the Red Breccia, and is onlapped mainly by the LGM-proglacial deposits. Downslope of Lepsius adit, the truncation surface dips steeply towards the left bank of the Inn river, which is cut into Triassic bedrock (cf. Fig. 1). The onlap of the LGMproglacial deposits indicates that much of the erosion of the Red Breccia and the Triassic bedrock took place already before the LGM.

Most investigations into the HB (or what was traditionally summarized as such) focussed on its central and eastern sector whereas the area between Höttinger Graben and Kranebitten gorge was mostly ignored (Fig. 3A). Outcrops of Red Breccia can be traced westwards to a ravine near Hochegg (850 m a.s.l.) (Fig. 3B). The toe of the mountain flank in that area is characterized by an array of slope facets (Fig. 3A). In the eastern sector from Planötzenhof to Fuchsegg, the slope facets mainly consist of proglacial deposits and overlying basal till of the LGM (PENCK 1921, p. $85 \mathrm{ff}$.). In the western sector from Fuchsegg to near Kerschbuchhof, the slope facets are smaller and consist of preLGM till and/or of the overlying package of conglomerates herein termed Peerhof Conglomerate (PC); the name is derived from outcrops close to the compound settlement Peerhof (Fig. 3B; see below for description).

At Kerschbuchhof near the western limit of our study area, a salient sediment package is present (Kerschbuchhof sediment body; KSB in Fig. 3B). The presence of the LGM index clast spectrum of the Inn ice stream (Tab. 2) indicates that this sediment body is related to the last glaciation, but its origin still is unclear. It was interpreted as a lateral moraine of a late-glacial Sulzenbach glacier debouching into the Inn valley (cf. Fig. 3A) (AMPFERER 1904, p. 115). It is unclear, however, whether a hypothetical ice flow from the Sulzenbach catchment was just debuttressed dead ice of the LGM (cf. REITNER 2007) or came from a local glacier actively supplied from the catchment. Alternatively, the KSB is a remnant of an alluvial fan formed in direct interaction with the decaying Inn ice stream (PENCK 1921, p. 89), perhaps even in a subglacial setting.

\section{Methods}

The succession described herein was mapped in the field on laserscan topographic images provided by the federal government of Tyrol (http://tiris.tyrol.at). Besides the field investigation of sedimentary facies, 20 cut slabs and 18 thin sections were used to document the deposits. Thin sections were inspected with a SZX10 Olympus Binocular. Inspection of thin sections was done with parallel-polarized, transmitted light under parallel and crossed nicols, respectively; in some cases, dark-field illumination proved better able to highlight the contrast between matrix and lithoclasts, and to indicate features of sediment deformation.

\section{Facies and facies distribution}

For the present investigation, ten facies associations were distinguished (Tab. 3). The most pertinent facies associations are described in more detail below, and include: (a) an interval of basal till of pre-LGM age, overlain by (b) a package of conglomerates (herein termed Peerhof Conglomerate, $\mathrm{PC}$ ) that was supplied by reworking of the till. The former two facies associations are overlain by (c) proglacial deposits and (d) basal till of the LGM. The proglacial to glacial deposits of the LGM also comprise large slope facets. In addition, the westernmost outcrop of Hötting Breccia (cf. Fig. 3B) is shortly described. Late-glacial to Holocene deposits are characterized only in Table 3.

\subsection{Basal till, Allerheiligen gravel pit}

In the abandoned Allerheiligen gravel pit, an interval up to more than $20 \mathrm{~m}$ in thickness of till is well-exposed (location 1 in Fig. 4; facies association \#1 in Tab. 2). The substrate of the till is a steeply-southward dipping truncation surface cut into Middle Triassic carbonate rocks ("Alpine Muschelkalk Group”, see Tab. 1). The truncation surface shows a differentiated metre-scale relief (Fig. 5A) and, in its accessible part, is polished and shows numerous striae, pressure marks, and scars from plucking of rock fragments. Together, the striae and the plucking scars indicate west-to-east ice flow. The till is rich in angular to rounded clasts of carbonate rocks up to a few decimetres in diameter; clasts derived from from reefal to perireefal environments of the Wetterstein Limestone are common (cf. Tab. 1). Less commonly, clasts of light-brownish dolostones, yellow to lightbrown cellular dolomites, and dark-grey to blackish limestones are present. Because such lithologies are present in several Triassic stratigraphic units of the NCA, the derivation of this latter clast suite is more difficult to deduce (see Tab. 1). In addition, a low but persistent content of clasts of light-brown to orange-weathering oncolithic limestones (oncolites) is present; these distinct clasts are derived from a few oncolite beds within the Northern Alpine Raibl beds (Carnian pro parte; Tab. 1). Over the entire vertical extent of exposure, clasts of metamorphic rocks are present but subordinate in abundance. The clast assemblage is characterized by diverse types of orthogneiss, green schist, paragneiss, (garnet) amphibolite, (garnet) mica schist, phyllite to calcphyllite, and quartzite. Despite detailed search, the index clast assemblage of the LGM Inn ice stream was not identified (cf. Tab. 2). Along the eastern flank of the gravel pit, till is also present, but is less well-exposed than the described till on the western flank. The overall characteristics of the eastern till interval are identical, i.e., no LGM Inn clast association was identified, the till is dominated by a lithoclast suite derived from the NCA, and the matrix is a light-grey to light-yellowish carbonate mud. Finally, the till is also well-exposed on the northern flank of the gravel pit (Fig. 5B); the characteristics of this till are the same as 
Tab. 3: Overview of facies associations in the study area.

Tab. 3: Übersicht der Faziesgemeinschaften im Untersuchungsgebiet.

\begin{tabular}{|c|c|c|}
\hline $\begin{array}{l}\text { Facies association } \\
\text { [or designator of association] }\end{array}$ & Characteristics & Interpretation, remarks \\
\hline $\begin{array}{l}\text { \#1 } \\
\text { Pre-LGM till } \\
\text { [?Riss] }\end{array}$ & $\begin{array}{l}\text { Overcompacted, mostly clast-supported diamict } \\
\text { with matrix of lime mud to carbonate-lithic 'pack- } \\
\text { stone' to diagenetic grainstone; clast shapes from } \\
\text { angular to well-rounded; clasts fractured in situ } \\
\text { common; many clasts with pressure marks, striae } \\
\text { are short; clast spectrum dominated by clasts from } \\
\text { NCA, low but persistent content of clasts of meta- } \\
\text { morphic rocks. }\end{array}$ & $\begin{array}{l}\text { Basal till of a pre-LGM Inn ice stream } \\
\text { [?Riss]. } \\
\text { Exposed best in gravel pit Allerheiligen [see } \\
\text { Fig. } 5 \text { A]. } \\
\text { See also PENCK [1921]. }\end{array}$ \\
\hline $\begin{array}{c}\# 2 \\
\text { Peerhof Conglomerate }\end{array}$ & $\begin{array}{l}\text { Medium- to thick-bedded, fine- to coarse-pebbly } \\
\text { conglomerates to conglobreccias; composed mainly } \\
\text { of clasts from NCA and low content of clasts of } \\
\text { metamorphic rocks; matrix: lithic grainstone to } \\
\text { packstone; stratal dip } 20-30^{\circ} \text {; locally clasts frac- } \\
\text { tured in situ }\end{array}$ & $\begin{array}{l}\text { Subaqueous part of a coarse-grained fan } \\
\text { delta or of talus shed into slow-flowing or } \\
\text { standing water, perhaps an ice-marginal } \\
\text { lake [see text]. }\end{array}$ \\
\hline $\begin{array}{l}\text { \#3 } \\
\text { Hötting Breccia [Red Breccia type], } \\
\text { westernmost outcrop }\end{array}$ & $\begin{array}{l}\text { [a] Subhorizontally very thick-bedded, disordered } \\
\text { breccias to conglobreccias; matrix: red-brown lithic } \\
\text { packstone; clasts derived from local mountain flank } \\
\text { [incl. clasts of Triassic red beds]; [b] intercalated } \\
\text { levels of poorly- to moderately- sorted openwork } \\
\text { conglobreccias with secondary matrix of lime mud- } \\
\text { stone }\end{array}$ & $\begin{array}{l}\text { [a] Deposits of subaerial cohesive debris } \\
\text { flows; } \\
\text { [b] deposits from ephemeral surface runoff } \\
\text { and winnowing of debris-flow layers } \\
\text { Westernmost outcrop of Red HB in PENCK } \\
\text { [1921] }\end{array}$ \\
\hline $\begin{array}{c}\text { \#4 } \\
\begin{array}{c}\text { Proglacial deposits of LGM Inn ice } \\
\text { stream }\end{array}\end{array}$ & $\begin{array}{l}\text { [a] Pebbly deposits rich in clasts of metamorphic } \\
\text { rocks, including index clast spectrum of LGM Inn } \\
\text { glacier; } \\
\text { [b] medium- to dark-grey micaceous sands to silts }\end{array}$ & Good exposures rare \\
\hline $\begin{array}{c}\text { \#5 } \\
\text { Basal till of the LGM Inn ice stream }\end{array}$ & $\begin{array}{l}\text { Overcompacted, matrix-supported diamict rich in } \\
\text { clasts of metamorphic rocks incl. LGM index clast } \\
\text { spectrum; medium-grey to dark grey matrix; many } \\
\text { lithoclasts polished, faceted and striated }\end{array}$ & $\begin{array}{l}\text { In-situ basal till only in two outcrops; in } \\
\text { all other exposures, the till is redeposited } \\
\text { [downslope creep, slopewash] } \\
\text { See Tab. } 2 \text { for index clasts }\end{array}$ \\
\hline $\begin{array}{c}\qquad \text { \#6 } \\
\text { Late-glacial: Fuchsegg Conglomerate }\end{array}$ & $\begin{array}{l}\text { Subhorizontally-bedded conglomerate composed } \\
\text { mainly of well-rounded clasts derived from NCA, } \\
\text { and clasts of metamorphic rocks; no cracked clasts } \\
\text { observed; cementation scarce }\end{array}$ & $\begin{array}{l}\text { Kames deposit of a channel along the ice } \\
\text { margin during decay of the LGM Inn ice } \\
\text { stream }\end{array}$ \\
\hline $\begin{array}{l}\text { \#7 } \\
\text { Late-glacial: Discrete bodies } \\
\text { of unlithified sediment }\end{array}$ & $\begin{array}{l}\text { Discrete bodies of uncompacted, unlithified peb- } \\
\text { bly deposits composed of subequal amounts of } \\
\text { lithoclasts derived from the NCA and metamorphic } \\
\text { clasts, including the LGM index clast spectrum }\end{array}$ & $\begin{array}{l}\text { LGM proglacial deposits and till, redeposited } \\
\text { during ice decay. } \\
\text { Poorly exposed, mainly in roadcuts; inter- } \\
\text { pretation based mainly on physical position } \\
\text { relative to other deposits } \\
\text { 'Kerschbuchhof sediment body' may pertain } \\
\text { to this category }\end{array}$ \\
\hline $\begin{array}{c}\text { \#8 } \\
\text { Late-glacial: } \\
\text { Veneers of redeposited till }\end{array}$ & $\begin{array}{l}\text { Veneers mainly on the frontal side of triangular } \\
\text { slope facets, up to } \sim 1 \mathrm{~m} \text { thick of compact mica- } \\
\text { ceous silt with scattered clasts of metamorphic } \\
\text { rocks up to small boulder size }\end{array}$ & $\begin{array}{l}\text { Veneers perhaps formed by downslope creep } \\
\text { and slopewash of LGM basal till. Origin not } \\
\text { fully clear, may also include aeolian dust. } \\
\text { May be mistaken for in-situ basal till }\end{array}$ \\
\hline $\begin{array}{l}\text { \#9 } \\
\text { Scree slopes and scree-paved } \\
\text { erosional chutes }\end{array}$ & $\begin{array}{l}\text { [a] Scree slopes of clasts derived from local rock } \\
\text { cliffs; [b] chutes between slope facets; in their } \\
\text { downslope part, the chutes are covered with soil, } \\
\text { forested or used as pasture; in their upslope part, } \\
\text { the chutes are paved with carbonate-rock clasts } \\
\text { derived from the upslope source areas }\end{array}$ & $\begin{array}{l}\text { Except for a few small, low-active areas in } \\
\text { the apical part of scree slopes or chutes, } \\
\text { these landforms are inactive and vegetated. } \\
\text { Active scree slopes today are confined to } \\
\text { areas typically > } 2000 \text { m a.s.l. }\end{array}$ \\
\hline $\begin{array}{l}\text { \#10 } \\
\text { Alluvial fans }\end{array}$ & $\begin{array}{l}\text { Alluvial fan of Sulzenbach [Kranebitten gorge] is } \\
\text { ephemerally water-run. Sulzenbach alluvial fan is } \\
\text { regulated by a concrete channel and run-of-river } \\
\text { dams }\end{array}$ & $\begin{array}{l}\text { Other alluvial fans that were active during } \\
\text { the late-glacial visible in laserscan; today } \\
\text { all these are inactive and vegetated [forest, } \\
\text { pasture] or blocked by buildings }\end{array}$ \\
\hline
\end{tabular}




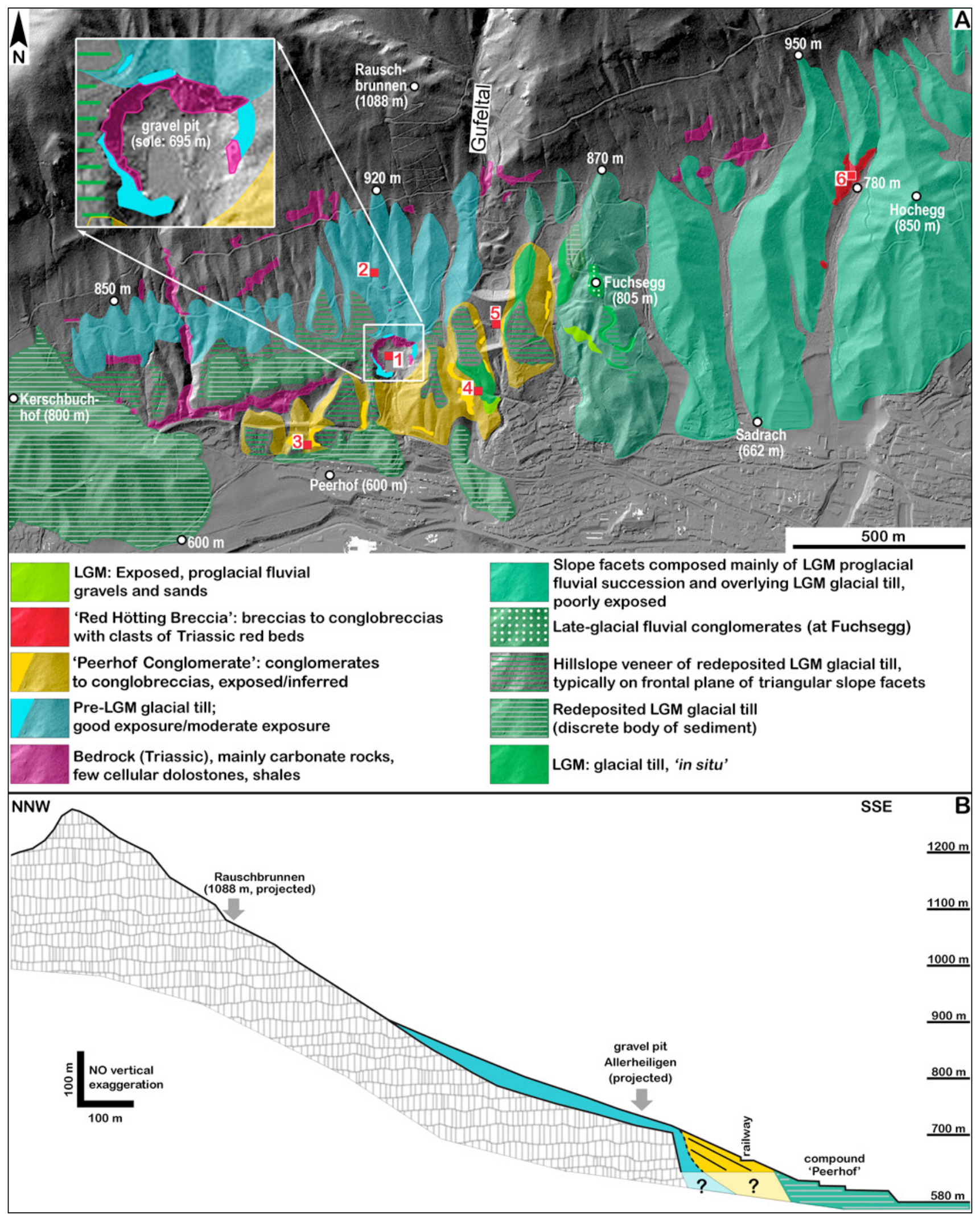

Fig. 4: A. Map of pertinent Quaternary deposits. Red numbers 1 to 6 denote key locations or areas (see text). Enlarged inset shows 'Allerheiligen' gravel pit where pre-LGM till is well-exposed. B. Schematic section upslope of Peerhof compound (type area of PC).

Abb. 4: A. Karte der relevanten quartären Ablagerungen. Die roten Nummern 1 bis 6 bezeichnen wichtige Aufschlüsse oder Bereiche (siehe Text). Der vergrößerte Ausschnitt zeigt die Kiesgrube ,Allerheiligen 'in der vor-letztglazialer Till gut aufgeschlossen ist. B. Schematischer Schnitt oberhalb der PeerhofSiedlung (Typus-Gebiet des Peerhof-Konglomerats). 
described, and it is in physical and compositional continuity with exposures of till directly upslope (area labeled 2 in Fig. 4A).

Within the main till outcrop along the western flank of the gravel pit, four intervals $\mathrm{A}$ to $\mathrm{D}$ were distinguished (Fig. 5A). (a) Interval A, characterized by very light-grey colour, is composed of a scarce matrix of lime mud rich in sand- to fine-pebble sized clasts (Fig. 5C); within this matrix, subangular to well-rounded clasts up to cobble size are embedded. Bedding or stratification were not observed in this interval, and the entire fabric is strongly compacted. (b) The overlying interval $B$ is sharply based by an outweathering, weakly lithified level approximately $5 \mathrm{~cm}$ in thickness that dips towards the Inn valley (145/45 dip/dip azimuth) (cf. Fig. 5A). Interval B is distinguished by a somewhat variable, but consistently higher amount of matrix giving rise to a light-yellowish colour in outcrop (Fig. 5D, $5 \mathrm{E})$. In interval $\mathrm{B}$, no difference to interval A was discerned with respect to the absence of bedding, the clast spectrum and relative amount of clast lithologies, clast rounding from angular to well-rounded, and extremely poor sorting. Except for the basal outweathering level, no planar fabric or stratification was found in interval $B$. (c) Interval $C$ in the upper part of outcrop (Fig. 5A) consists of very poorlyto moderately sorted, fine to coarse pebbles with a matrix of winnowed silt to sand (Fig. 6A). (d) The topmost interval $\mathrm{D}$ is based by a well-identifiable, sharp surface that locally shows a festooned shape (Fig. 5A, 6B, 6C). Internally, interval D shows a complex arrangement of different deposits, characterized by outweathering beds of: (i) winnowed carbonate-lithic arenite with mica flakes and a few grains of quartz and feldspar, (ii) lenses of lithified sediment with characteristics similar to interval B (Fig. 6D, 6E, 6F), and (iii) conglobreccias with a primary matrix of lithic wackestone, and with patches of openwork clast fabrics lithified by interstitial calcite cement (Fig. 7A, 7B, 7C). In between the outweathering lithified beds, irregularly-shaped lenses and pods of sediment comparable to intervals $\mathrm{A} / \mathrm{C}$ and intervals $B$ are intercalated.

\subsection{Slope facets of till, upslope of gravel pit}

Along the mountain flank upslope of the gravel pit, an array of slope facets is present (area labeled 2 in Fig. 4). Several forest roads leading up und along this part of the mountain flank provide fairly continuous exposure; the roadcuts expose till rich in clasts derived from the NCA. The till overlies bedrock (Alpine Muschelkalk Group and Hauptdolomit unit; cf. Tab. 1), and is rich in clasts with polished surfaces, pressure marks and glacial striation. In the till, clasts from the Wetterstein Formation prevail; in addition, clasts up to cobble size of oncolites from the Northern Alpine Raibl beds are relatively rare but persistent (Fig. 7D; see Tab. 1). Metamorphic rock fragments are uncommon to subordinate. Despite detailed search in the roadcuts, the LGM index clast association of the Inn ice stream was not identified (cf. Tab. 2). Uphill, the slope facets lower and taper out, and merge with the surface of post-glacial scree slopes supplied from rock cliffs upslope. The slope facets of till are laterally separated by bedrock-incised chutes, or more commonly, by vegetated chutes incised into the till.
Downslope, the chutes widen, and are littered with fragments of metamorphic rocks. In addition, the frontal sectors of triangular slope facets excavated from the described till are veneered with a layer of compact, micaceous silt to sand with clasts of metamorphic rocks (Fig. 4A, Tab. 3). Within both the lower part of the chutes littered with metamorphic rock fragments, and in the veneers on the frontal sides of triangular slope facets, the index clast association of the LGM Inn ice stream was identified. This indicates that the downslope part of the chutes incised into the till, and the frontal face of the triangular slope facets, is veneered with reworked basal till of the LGM (cf. Fig. 4A).

Towards the West, the described slope facets of till terminate closely east of a small ravine along the limit of the Kerschbuchhof sediment body (cf. Fig. 3B, 4A). Along this ravine, and particularly at its downslope end, clasts of metamorphic rocks including a few clasts of the LGM index spectrum (dark green garnet amphibolite, Julier granite) (cf. Tab. 2) are common. Eastward of the Gufeltal ravine, in turn, the described slope facets of till are followed by slope facets of different composition and larger size that can be clearly ascribed to the LGM (Fig. 3B, 4A) (see below for description).

\subsection{Peerhof Conglomerate [PC]}

Easily accessible outcrops of this succession are present directly north of the compound settlement Peerhof at $47^{\circ} 16^{\circ} 12^{\prime \prime} \mathrm{N} / 11^{\circ} 20^{\prime} 35^{\prime \prime} \mathrm{E}$; hence, we chose this name for the entire lithosome (Fig. 3B, location 3 in Fig. 4, Fig. 7E). From there, the $\mathrm{PC}$ can be traced over a total distance of roughly one kilometre (Fig. 3B, 4, 7F). Field relationships and an outcrop along a roadcut indicate that the $\mathrm{PC}$ overlies the described till (Fig. 8A). The features of the PC are relatively constant in all of its outcrops. Most distinct are a dip of bedsets in the range of $22-32^{\circ}$, amalgamated bedsets giving rise to thick and faint stratification, and a few layers of well-sorted openwork clast fabric (Fig. 8B-C). In the amalgamated beds, lithoclasts float with their [a,b] axial plane subparallel to stratification, or show downdip clast imbrication; lithoclasts of medium pebble to cobble size float within their matrix. The matrix is a winnowed carbonate-lithic arenite with a few metamorphic rock fragments. The rounding of lithoclasts ranges from subangular to well-rounded; in consequence, the fabric ranges from conglomerates to, less commonly, conglobreccias. Locally, thin strata of well-sorted, clast-supported conglomerates with a matrix of winnowed carbonate-lithic arenite are intercalated. In outcrop and thin section, in the PC, a few lithoclasts cracked in situ were identified.

The clast spectrum of the PC is dominated by rock fragments from the Wetterstein Formation and, subordinately, from other Triassic stratigraphic units of the NCA (Fig. 8DE); overall, the NCA-derived clast spectrum does not show an obvious difference to that of the underlying till. Similarly, the conglomerate contains a subordinate but persistent amount of clasts of metamorphic rocks. Field inspection of the metamorphic clast spectrum and thin sections of selected clasts again could not identify the index clast spectrum of the LGM Inn ice stream (PernREITER 2014). Near Peerhof, the conglomerate is shaped by erosion into large 


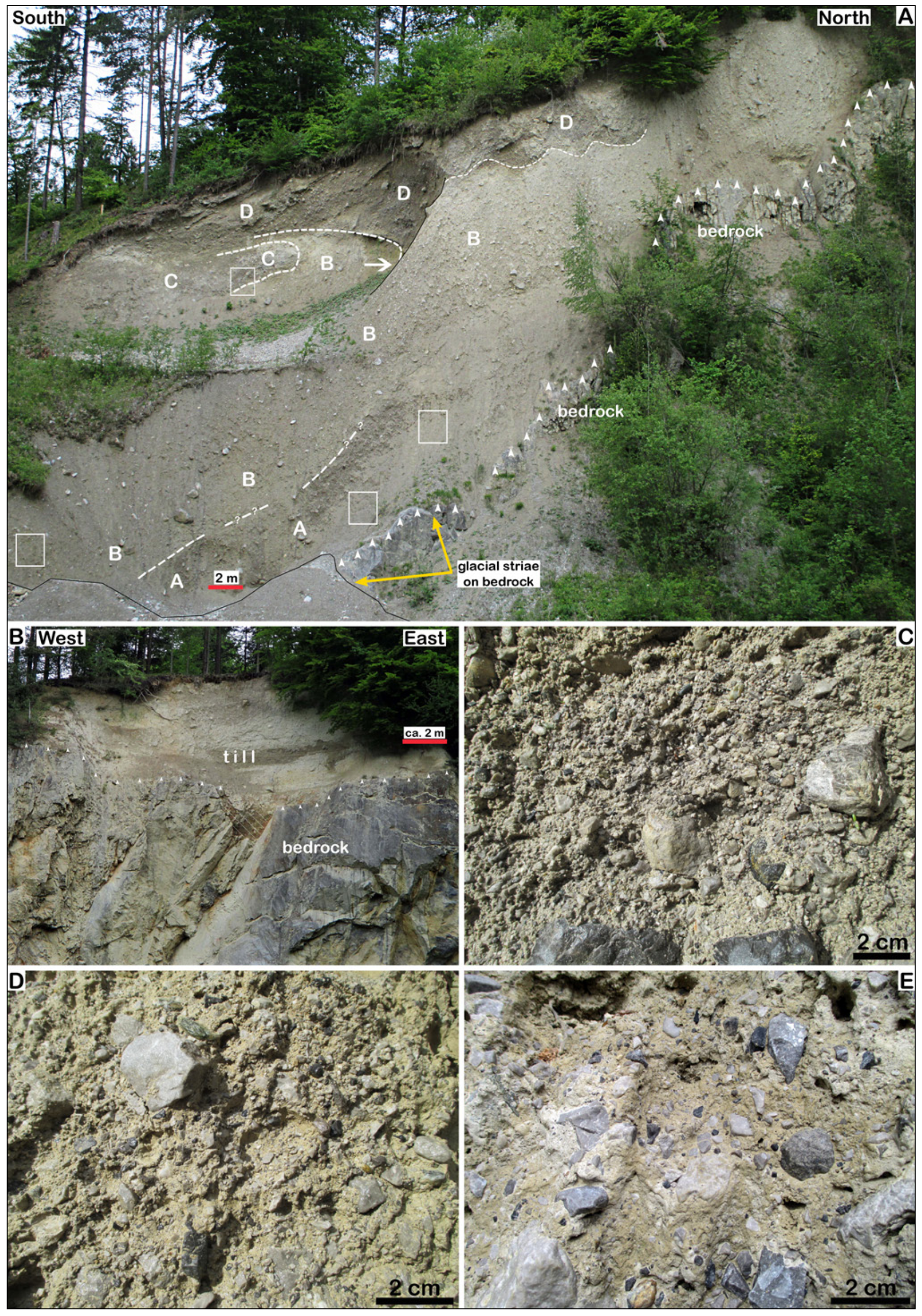

Caption p. 14, Bildunterschrift S. 15 
Fig. 5: A. Western flank of Allerheiligen gravel pit. Pre-LGM till overlies a south-dipping truncation surface (white arrowtips) on carbonate rocks ("Alpine Muschelkalk Group", cf. Tab. 1). Letters A to D: intervals distinguished in the till. Rectangles and arrow: excavations. B. Northern cliff of gravel pit. The interval of pre-LGM till is contiguous into slope facets exposed along roadcuts a few metres upslope (cf. Fig. 4A). C. Detail of interval A: Clast-supported fabric of sand to coarse, angular to subrounded pebbles. Sparse matrix is lime mud. D. Detail of interval B: Clast- to matrix-supported fabric of sand to coarse, angular to subrounded pebbles. Matrix is a carbonate-lithic wacke to arenite with matrix of lime mud. E. Detail of upper part of interval B: Matrixsupported fabric of very poorly sorted sand to coarse pebbles. Matrix is a carbonate-lithic wacke with matrix of lime mud.

Abb. 5: A. Aufschluß des prä-LGM Tills, Westflanke Kiesgrube Allerheiligen. Der Till liegt auf einer südfallenden Trunkationsfläche (weiße Pfeilspitzen) auf Karbonatgesteinen („Alpine Muschelkalk Gruppe“, vgl. Tab. 1). Buchstaben A bis D: Intervalle im Till. Rechtecke und Pfeil: künstliche Freilegungen. B. Nördliche Wand der Kiesgrube. Der prä-LGM Till geht in Hangfacetten über, die wenige Meter bergaufwärts in Fahrweg-Anrissen erschlossen sind (vgl. Abb. 4A). C. Ausschnitt Intervall A: Klastengestütztes Gefüge aus Sand bis Grobkies aus angularen bis subgerundeten Klasten. Matrix ist Kalkschlamm. D. Ausschnitt Intervall B: Klasten- bis matrixgestütztes Gefüge aus Sand bis Grobkies aus angularen bis subgerundeten Klasten Matrix: karbonat-lithische Wacke bis Arenit (Packstone-Textur). E. Ausschnitt Intervall B: Matrix-gestütztes Gefüge aus Sand bis Grobkies aus angularen bis subgerundeten Klasten. Matrix: karbonat-lithoklastische Wacke (Kalkschlamm-Grundmasse) bis Arenit (Packstone-Textur).

triangular slope facets. Towards the East, the conglomerate is overlain by deposits clearly related to the LGM, including till and reworked till of the LGM (locations 4 and 5 in Fig. 4A). The PC terminates some 100 metres eastward of the Gufeltal ravine (cf. Fig. 4A).

\subsection{Slope facets east of Gufeltal ravine}

East of Gufeltal ravine, a marked increase in size and a change in composition of slope facets is obvious (Fig. 4A). In their stratigraphically lower part, these slope facets are composed of proglacial deposits related to the advance of the Inn ice stream during the LGM. The proglacial deposits are fluvial gravels and sands rich in metamorphic rock fragments. The stratigraphically upper part of the slope facets consists of (redeposited) basal till of the LGM. Outcrops, however, are scarce as most of the area is covered by forest. Even in the few outcrops provided by roadcuts, because of the steep flanks of the slope facets, it is doubtful whether till-like deposits or sandy-gravelly deposits in the exposed near-surface layer are preserved in place. The relocation of the stratigraphic boundary between proglacial deposits and overlying basal till proved practically impossible. Because of these complications, we refrain from showing these slope facets in more detail. In addition, toward the apical part of the slope facets, the LGM-derived clast spectrum becomes progressively diluted with scree derived from the rock cliffs above, i. e. all of the material is redeposited, and modified in composition. This dilution and mixing with post-glacial local scree is obvious along a forest road leading along the apical parts of the facets between 850-860 $\mathrm{m}$ a.s.l. Even under these conditions, however, in the outcrops along that road, the index clast spectrum of the LGM Inn ice stream can be identified (cf. Tab. 2).

In the westernmost large slope facet - sufficiently exposed to allow for local distinction of units - the LGM basal till overlies a surface dipping toward the Inn valley. In addition, on the hillock Fuchsegg (Fig. 4A), a conglomerate herein termed Fuchsegg Conglomerate is present. This deposit consists of subhorizontally-stratified, moderately to well-sorted, fine- to coarse-pebbly conglomerates of wellrounded clasts derived from the NCA and clasts of metamorphic rocks (Fig. 8F). Within the indicated range, mean grain size and sorting vary substantially among strata. Despite the clast-supported conglomerate fabrics, no clasts fractured in situ were seen. Mapping suggests that the
Fuchsegg Conglomerate and the underlying till of the LGM are separated by a surface of erosion.

\subsection{Hötting Breccia, westernmost outcrop}

Approximately 800 metres east of the termination of the PC, between 780-815 m a.s.l., Red Hötting Breccia is exposed at the head of a ravine between slope facets (location 6 in Fig. 4). Stratification in the breccia dips with a few degrees to the South, out into air. The exposed succession is approximately 30 metres in thickness, and consists of very thick beds of clast-supported, moderately sorted to very poorly sorted conglobreccias and breccias. Locally, intervals up to a few decimetres in thickness of faintly decimetre-stratified, moderately-sorted, medium to coarse-pebbly conglomerates ar intercalated. In field and thin section, the deposit pertains to the Red Breccia lithotype, i. e. a breccia to conglobreccia with clasts of Triassic red reds and with a matrix of brownish to pink-coloured lime mudstone. The lithoclasts mainly are derived from reefal- to perireefal facies of the Wetterstein Limestone; an additional suite of dolostones probably derives from the Hauptdolomit unit and/or from dolomitized portions of the Alpine Muschelkalk Group (cf. Tab. 1). An accessory yet persistent content of clasts of metamorphic rocks also is present in this breccia. Drillholes show that this breccia was formerly quarried.

\section{Interpretation \\ 5.1 Basal till, Allerheiligen gravel pit}

The till exposed in the gravel pit is not comparable to the clear-cut LGM till as exposed higher upslope. The LGM till in the area of Innsbruck is characterized by overall richness in clasts of metamorphic rocks, in particular the index clasts Julier granite and garnet amphibolite (see Tab. 2). The till of the gravel pit yet is broadly similar to "preLGM" tills of unknown age in the environs of Innsbruck (cf., e.g. Ampferer 1903, Penck 1921, Heissel 1954, Klacki 2015): A composition rich in clasts derived from the NCA, a spectrum of metamorphic rock fragments that seems not to contain a distinct association of index clasts (or not identified as yet), and a light yellowish to light grey coloured matrix. Potential reasons for the relative abundance in NCAderived clasts might include: (a) a marked lateral segregation of glacial drifts from different source areas on the ice stream, and/or (b) a different flow pattern of ice streams 

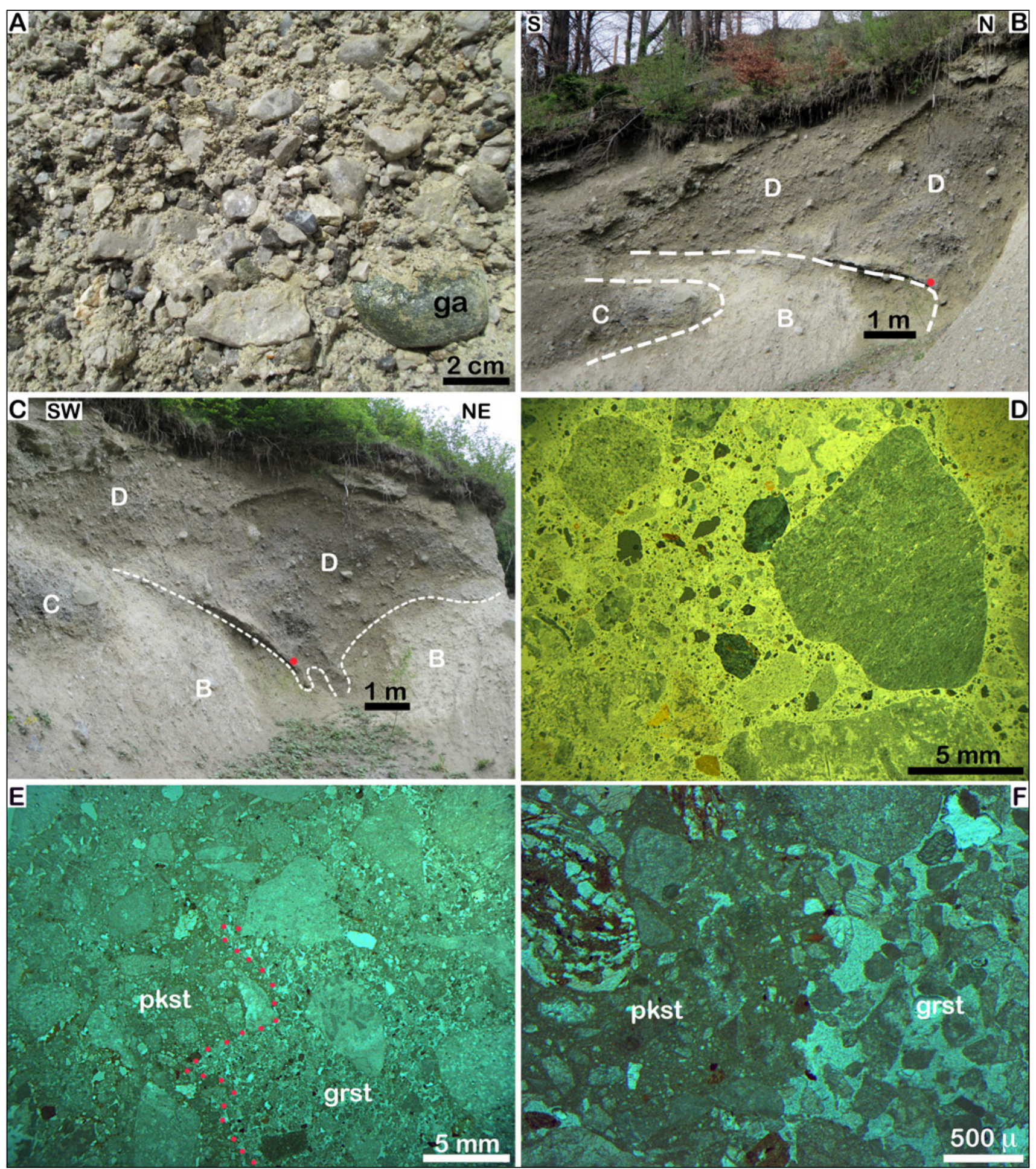

Fig. 6: A. Detail of interval C (cf. Fig. 5A). Clast-supported fabric of sand to coarse, subangular to well-rounded pebbles. Clast 'ga' is garnet amphibolite. Matrix is winnowed arenite. B, C. Till intervals C to D (cf. Fig. 5A). Outweathering levels are lithified; red dot (sample) marks well-lithified conglobreccia. D. Thin section of conglobreccia (cf. Fig. 6C). Note disordered clast fabric, extremely poor sorting, and shapes from angular to subrounded. Matrix is lithified lime mud. Crossed nicols, dark-field illumination. E. Thin section of lithified level in interval D. The pebble fraction is dominated by angular to rounded fragments of Wetterstein Limestone. A domain of grainstone (grst) sharply abuts a domain of packstone (pkst) along a boundary of highly irregular shape (red dots). F. Detail of Fig. 6E. Sharp irregular boundary between packstone (pkst) and laterally adjacent grainstone (grst).

Abb. 6: A. Ausschnitt von Abschnitt C (cf. Abb. 5A). Klastengestütztes Gefüge aus Sand bis Grobkies aus subangularen bis gut gerundeten Klasten. Klast ,ga': Granatamphibolit. Matrix: ausgewaschener Arenit. B, C. Till-Intervalle C bis D (cf. Abb. 5A). Die vorwitternden Niveaus sind lithifiziert. Der rote Punkt markiert eine gut lithifzierte Lage von konglomeratischer Brekzie (Probe). D. Dünnschliff der konglomeratischen Brekzie (cf. Abb. 6C). Beachte das ungeordnete Gefüge, die extrem schlechte Sortierung, sowie die Spanne von angular bis subgerundet. Matrix ist lithifizierter Kalkschlamm. Gekreuzte Nicols, Dunkelfeld-Beleuchtung. E. Dünnschliff der lithifizierten Lage im Intervall D (cf. Abb. 6C). Die Kiesfraktion ist sehr schlecht sortiert und besteht vorwiegend aus angularen bis gerundeten Klasten aus Wettersteinkalk. Ein Bereich aus Grainstone (grst) stößt scharf an einen Bereich aus Packstone (pkst) entlang einer unregelmäßigen Grenze (rote Punkte). Durchlicht, parallele Nicols. F. Ausschnitt von Abb. 6E. Scharfe, unregelmäßige Grenze zwischen Packstone (pkst) mit grau erscheinender Kalkschlamm-Matrix und dem benachbarten Grainstone (grst). Durchlicht, parallele Nicols. 
from tributary valleys relative to flow patterns of the LGM.

In the gravel pit, a composition of the till rich in clasts from the NCA, and devoid of index clasts of the LGM Inn ice stream, might also result from congestion of ice of the southerly Sill glacier against Nordkette (cf. Fig. 1). VAN Husen (2000) and ReITner (2011) suggested that, because of its high-positioned and large catchment, the Sill glacier debouched into the Inn valley at Innsbruck before approach of the Inn ice stream. If so, at the position of the gravel pit, the congested Sill-glacial ice should have flowed up-stream along the left flank of the Inn valley, toward the West (cf. Fig. 1). To test this hypothesis, the clast spectrum at the exit of Sill valley was inspected and sampled several times. Aside of less indicative, widespread lithologies (e.g. quartz phyllite, calcphyllites), the Sill clast spectrum shows a suite of mafic to ultramafic rocks such as diabase, gabbros and serpentinites; furthermore, ophicalcites and banded marbles are typical (PernReiter 2014, RÜMmele 2015). This clast spectrum was not identified in the till of the gravel pit. In addition, an origin of the till from congested Sill ice seems also precluded by the west-to-east directed glacial striae and pluckings on the bedrock surface in the gravel pit.

Aside of a composition mainly of clasts from the NCA, two major features of the till in the gravel pit are: (a) the composition of different intervals A to D with distinct characteristics, and (b) the evidence for intense deformation of and within these intervals. Over most of its vertical extent, the till is supported by the sand- to pebble-sized sediment fraction, is relatively poor in matrix, and matrix-supported diamicton is absent. In intervals $\mathrm{A}$ and $\mathrm{C}$, and in some levels of interval $\mathrm{D}$, the rounding of many of the lithoclasts, and the matrix of winnowed sand to silt suggests that these sediments originally water-laid; subsequent to deposition, they became subject to subglacial deformation and compaction. Interval A might represent a vestige of proximal proglacial-fluvial deposits overridden by advancing ice; alternatively, the deposits of interval A accumulated from subglacial runoff. Whatever the origin of interval A, the absence of stratification or other features of hydrodynamic deposition indicates that the sediment became homogenized, compacted and deformed subsequent to deposition. For interval $\mathrm{C}$ and the clast-supported levels within interval $\mathrm{D}$, an original subglacial-fluvial deposition similarly seems probable; this is suggested by the strong compaction of the sediments combined with the clast-supported composition of subangular to well-rounded lithoclasts. In interval D, the outweathering levels of slightly cemented, carbonate-lithic siltite to arenite most probably were beds of primary sedimentary origin that became deformed and compacted after deposition. Observations beneath active glaciers suggest that intermittent phases of high basal water pressures may lead to separation of the glacier from its bed, leading to subglacial deposition of pebbly and sandy deposits (e.g. Hoffmann \& Piotrowski 2001, Hart, Rose \& MARTINEZ 2011).

The outweathering, lithified level along the base of interval B and the lithified levels in interval D are all present along the boundary between sediments of different fabric. The polished slabs and thin sections show that these lithified levels originally had a matrix of lime mud; this matrix, however, locally has been removed by eluviation and disso- lution, accompanied with lithification of the lime mud and precipitation of cement in interstitial pores of diagenetic grainstone to rudstones (cf. Fig. 6E-F, 7A-C). It is assumed that the first step in forming these levels was related to glacial loading followed by shearing, leading to compaction and dewatering of the fabric. Groundwater then preferentially percolated adjacent along the sheared levels, which led to localized dissolution-reprecipitation of lime mud, and to cement precipitation in pore space produced by eluviation/dissolution. Because of the evidence for intense subglacial deformation at least in the upper part of the exposed interval, the till can be considered as a deformation till (e.g. Dreimanis 1993, Aber \& Ber 2007) or 'soft lodgement till' (RuszCZynska-SzEnAJCH 2001). In the classification of MenzIEs (2012), in turn, the till of the gravel pit would classify as a type B till, or as a mélange or tectomict. Type B till is inferred to form under conditions of fluctuating, low to high strain from glacier movement related to fluctuations of subglacial water pressure (MEnzies 2012, see also Boulton, DoBBIE \& ZATSEPIN 2001). In summary, the characteristics of the sediments and the deformation of intervals $A$ to $D$, as well as the glacially-striated, plucked bedrock surface suggest a warm-based ice stream with subglacial runoff.

\subsection{Slope facets of till, upward of gravel pit}

Adjacent to and upslope of the gravel pit, till of identical characteristics as the till within the pit is exposed along several roads cutting across slope facets. At first glance, one might assume that these slope facets represent paraglacially reworked till diluted by clasts from the NCA, and formed during ice decay of the LGM. If so, the LGM index clast spectrum should be present; as described, this is not the case. One might alternatively assume that the slope facets consist of till of a late-glacial local glacier. In the considered area, only two catchments might have supplied glaciers that potentially reached down to $700-800 \mathrm{~m}$ a.s.l., that is, the cirques in the catchment of Sulzenbach, and the Schneekar cirque (cf. Fig. 3A); for the latter, because of necessary lowering of the equilibrium line altitude (ELA) of glaciers, it seems highly doubtful whether it could sustain a single glacier down to an altitude of 700-800 m a.s.l., without wholesale glaciation. Even if so, the composition of the slope facets located between the debouches of these two hypothetical local glaciers could be hardly explained, because of: (a) the absence of LGM index clasts, despite presence of metamorphic rock fragments in the till, and (b) the low but persistent content of oncolite clasts. Because the catchment of Gufeltal is devoid of Northern Alpine Raibl beds, in a local glacier hypothesis, these clasts could derive only from the Sulzenbach catchment. This, in turn, would require very wide and high-positioned lateral spread of a late-glacial Sulzenbach glacier, a hypothesis that (i) seems hardly compatible with the composition and shape of the Kerschbuchhof sediment body, and (ii) fails to explain the absence of Inn LGM index clasts in the slope facets. Finally, the geological mapping indicates that a veneer of redeposited LGM till and, at other locations, in situ LGM till overlies the slope facets (Fig. 4A). The most parsimonious explanation for the position and composition of the discussed slope facets hence is that they consist of pre-LGM till. In 



Fig. 7: A. Thin section of level shown with red dot in Fig. 6B-C. Conglomerate of carbonate rocks and a few clasts of metamorphic rocks. Interstitial space is filled with lithic wackestone. In the upper part, dissolution pores (black) and clast interstitials with calcite spar are present. Crossed nicols. B. Detail of Fig. 7A: Clast interstitials filled with calcite cement (cc), and a remnant of intersitial matrix (mt). Crossed nicols, dark-field illumination. C. Thin section of conglobreccia of carbonate rocks and metamorphic rocks. Matrix is lithic wackestone. In the upper part, dissolution pores (d) are present. Parallel nicols. Inset: cracked clast with matrix-filled fractures. Crossed nicols, dark-field illumination. D. Oncolite clast from the Northern Alpine Raibl beds (cf. Tab. 1), found in slope facets of till uphill of Allerheiligen gravel pit (area number 2 in Fig. 4A). E. PC at $645 \mathrm{~m}$ a.s.l. at the type location north of Peerhof compound (location 3 in Fig. 4A). With of view $\sim 20 \mathrm{~m}$. F. PC at $680 \mathrm{~m}$ a.s.l. near location 4 (cf. Fig. 4A). Width of view $\sim 7 \mathrm{~m}$.

Abb. 7: A. Dünnschliff der lithifizierten Lage im Intervall D (roter Punkt in Abb. $6 B-C$ ). Konglomerat aus Karbonatgesteinen und wenigen Komponenten aus Metamorphiten. Der Zwickelraum ist mit lithischem Wackestone gefüllt; im oberen Teil sind Lösungsporen (schwarz) sowie Kalzitzement vorhanden. Gekreuzte Nicols. B. Ausschnitt von Abb. 7A: Zwickelräume mit Kalzitzement-Füllung (cc) sowie den Rest einer früheren Matrix (mt). Dunkelfeld-Beleuchtung, gekreuzte Nicols. C. Dünnschliff einer klastengestützten konglomeratischen Brekzie aus Karbonatgesteinen und einigen Metamorphit-Komponenten. Matrix ist lithischer Wackestone. Beachte die Lösungsporen (d). Parallele Nicols. Kleinbild: in-situ geknackter Lithoklast, mit Kalkschlamm-Matrix entlang der Brüche. Dunkelfeld-Beleuchtung, gekreuzte Nicols. D. Oncolith-Klast (aus den Nordalpinen Raibler Schichten, vgl. Tab. 1) im Till, der die Hangfacetten oberhalb der Kiesgrube Allerheiligen bildet (Bereich Nummer 2 in Abb. 4A). E. Peerhof-Konglomerat bei 645 m ü.d.M. an der Typlokalität nördlich der Peerhof-Siedlung (Örtlichkeit 3 in Abb. 4A). Bildausschnitt 20 m. F. Peerhof-Konglomerat bei 680 m ü.d.M. nahe der Ortlichkeit 4 in Abb. 4A. Bildausschnitt $\sim 7 \mathrm{~m}$. 
his geological map of the Hötting Breccia, PENCK (1921) showed only the relatively small outcrops of pre-LGM till along Gufeltal ravine and close to the gravel pit. Upslope of the gravel pit, where the slope facets of till are located, he indicated bedrock and patches of LGM till. In view of the overall precision and correctness of his mapping, this is most probably related to poor exposure at his time.

\subsection{Peerhof Conglomerate}

Because no obvious difference in the clast spectra, NCAderived and metamorphic, between the $\mathrm{PC}$ and its underlying till was identified, the conglomerate probably was supplied - largely at least - from reworking of the till. The time lapse between till formation and deposition of the PC is however unknown. The stratal dips of $\sim 20-30^{\circ}$ may suggest that the PC represents a subaerial talus apron supplied from the till higher upslope. Mapping indicates that at least in the area between Peerhof and Allerheiligen gravel pit, the PC overlies a steeply southward-dipping surface of erosion on top of the till. In the Hötting Breccia, proximal slope segments of subaerial scree slopes with stratal dips up to more than $30^{\circ}$, and onlapping subvertical substrates, are well-documented (PENCK 1921, WEHRLI 1928, SANDERS 2010, SANDERS \& SPÖTL 2014). The setting of the $\mathrm{PC}$, however, renders an origin from a subaerial scree slope improbable. First, prolonging the stratal dips upslope, to arrive at a geometrically required onlap surface would imply a thickness of the pre-LGM till in the range of hundreds of metres. Second, even if such a thickness of the till would be allowed for, the facies association of the PC were highly atypical of the proximal slope segment of subaerial talus; this slope segment typically consists of decimetre- to metre-stratified successions characterized by an alternation of (i) gently lense-shaped levels with openwork clast fabric with (ii) clast-supported strata with a matrix of carbonate mud. In addition, primary openwork clast fabrics may be partly or entirely filled with a secondary matrix of geopetally-laminated carbonate mud; furthermore, the former scree slope surface as a proxy for stratification is typically imaged by levels up to a few centimetres in thickness of illuviated secondary matrix (SANDERS et al. 2009). In the PC, no more-or-less regular interlayering of openwork and matrix-bearing strata, and no secondary matrix fabrics have been observed.

For the PC the widely-spaced stratal surfaces between amalgamated bedsets dipping with up to more than $30^{\circ}$, the widespread matrix of winnowed carbonate-lithic sand to silt, the intercalated lenses of well-sorted openwork clast fabrics of rounded clasts, and the variable degree of clast rounding - with a prevalence of subrounded to rounded shapes - all suggest that the conglomerate accumulated in a subaqueous setting. The variable proportion but overall predominance of rounded clasts over angular-subangular clasts suggests a limited degree of rounding, i. e. a short transport route perhaps up to a few hundreds of metres before final deposition. Many of the rounded clasts may also have been inherited from the underlying till, which is relatively rich therein (see above). The PC is interpreted as the subaqueous portion of a fan delta or of laterally coalesced, small fan deltas or scree slopes; these were sup- plied from reworking of the till, perhaps by shedding into an ice-marginal lake. Proglacial lakes with fan deltas and scree slopes supplied by redeposition of till are widespread in valleys undergoing deglaciation (e.g. CHURCH \& RydER 1972, Johnson 1984, Ballantyne \& Benn 1994, Curry, Cleasby \& Zukowskyj 2006, Ravazzi et al. 2012), and today are common along decaying ice streams, for instance, in the northwestern part of the Rocky Mountains (Alaska, Yukon, British Columbia) (Fig. 9). Both, the scales in space and the variability in type of paraglacial deposystems from scree slopes shedding directly into lakes, to fan deltas - are comparable to that of the PC and the associated mountain flank (cf. Fig. 4).

\subsection{Slope facets east of Gufeltal ravine}

The described succession and the clast spectrum of the large slope facets to the East of Gufeltal ravine indicate that they accumulated from proglacial and subglacial deposition during the LGM (Fig. 4A). As mentioned, only the westernmost slope facet is sufficiently exposed to allow for distinction of units. The described Fuchsegg Conglomerate (Fig. 4A, 8F) is interpreted as a late-glacial ice-marginal deposit. This is suggested by: (a) the relation between underlying till and overlying conglomerate suggestive of an erosional base of the conglomerate, and (b) by the absence of clasts cracked in situ in the conglomerate. In Höttinger Graben, in pebbly proglacial fluvial deposits of the LGM, many of the pebbles are cracked or crushed at point contacts due to glacial loading (SALVEMINi 2013). Still farther east, in turn, downslope of Lepsius adit, a fluvio-deltaic conglomerate with uncracked clasts is present (PENCK 1921). U/Th ages of calcite cements of the conglomerate are of Holocene age; the cement ages and the geological context suggest that conglomerate depositon took place during the late-glacial (SANDERS \& SPÖTL 2014). Together, this suggests that the Fuchsegg conglomerate, with its uncracked clasts and positioned above the basal till, is of late-glacial age.

In the considered area, the west-to-east change in the composition of slope facets coincides with a distinct northward retreat of the topographically lowest bedrock exposures (Fig. 3B, 4). Along strike roughly parallel to the local WSW-ENE strike of the Inn valley, the bedrock surface east of Gufeltal ravine is located at a lower altitude than westward thereof. The preserved extent of the PC suggests that its upper margin roughly follows a bedrock step in the subsurface (Fig. 3B). The shaping of the large slope facets by erosion proceeded mainly during to shortly after the last ice decay, before hillslopes became stabilized by vegetation. The shape of the present slope facets and the intercalated ravines suggests that - down to the level of the ravines - roughly half of the original sediment volume (LGM proglacial deposits plus till) was eroded. The extent in depth of the LGM deposits, the shape of the bedrock surface, and potential older Quaternary deposits underneath the slope facets, however, are unknown.

\section{Discussion}

In the westernmost outcrop of Red Hötting Breccia (location 6 in Fig. 4A) the facies types, clast spectrum and 

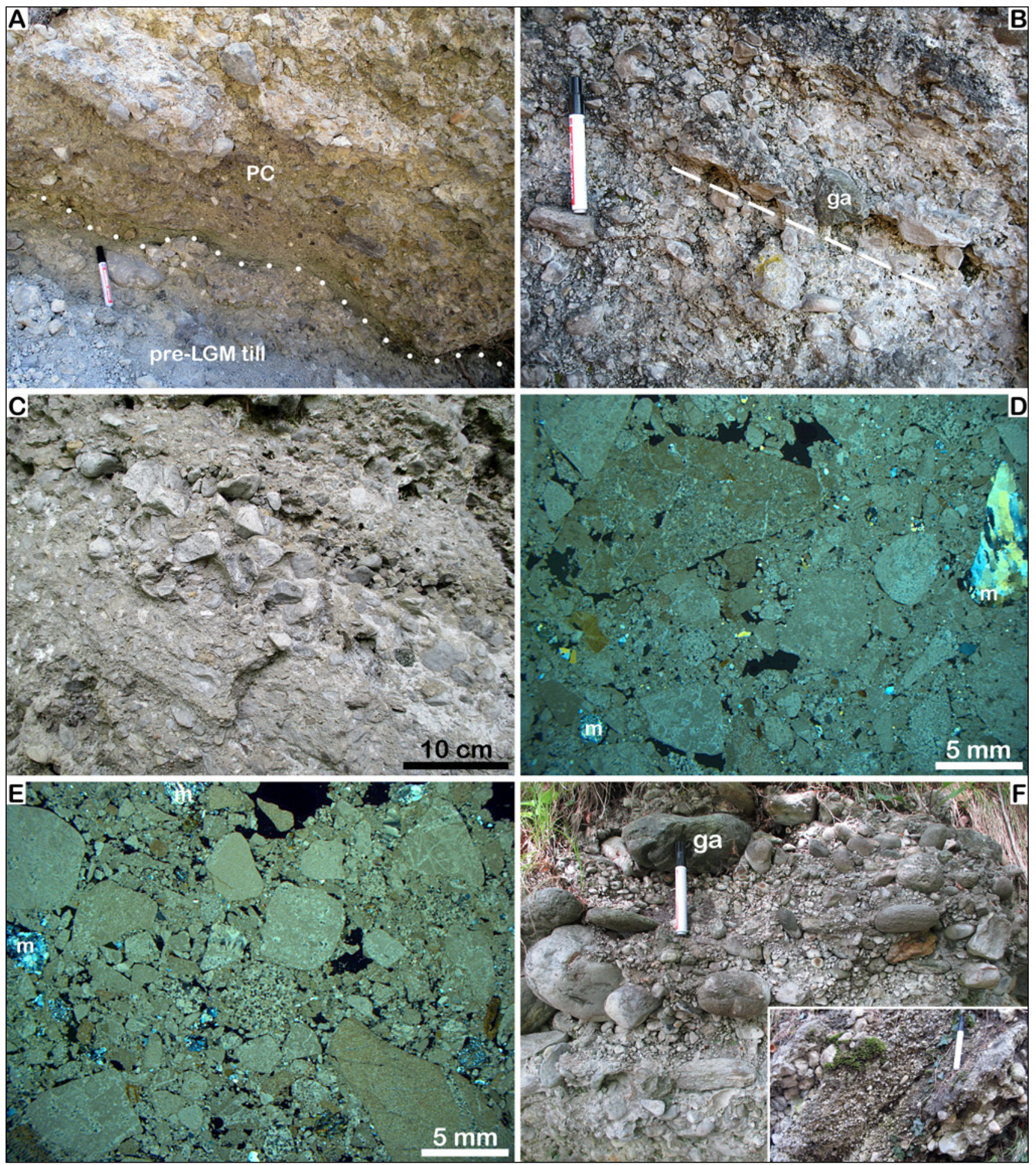

Fig. 8: A. Boundary (dots) between pre-LGM till and PC (location 5 in Fig. 4A). Pen is $14 \mathrm{~cm}$ long. B. PC $\sim 70 \mathrm{~m}$ downdip of location 5 (cf. Fig. $4 \mathrm{~A})$. Very thick beds with faint strata (dashed line) seen by parallel clast alignment. 'Ga': garnet amphibolite. Pen is $14 \mathrm{~cm}$ long. C. PC from same location as Fig. 8B. Lower and upper part of photo: very poorly-sorted, fine to coarse pebbly conglomerates; central part: stratum of moderately-well sorted, medium-coarse pebbles (matrix: lithic arenite) overlain by lense with openwork clast fabric. D. Thin section of PC from type location (location 2 in Fig. 4A). Note: (i) composition of subrounded to well-rounded clasts of carbonate rocks (mainly Wetterstein Limestone) and a few clasts of metamorphic rocks ( $m$ ), (ii) densely packed clast fabric, and (iii) dissolution pores (black). Crossed nicols. E. Thin section of PC from outcrop at $725 \mathrm{~m}$ as.l., $120 \mathrm{~m}$ NW of location 4 (cf. Fig. 4A). Note: (i) composition of subrounded clasts of carbonate rocks (mainly Wetterstein Limestone) and a few clasts of metamorphic rocks (two labeled $\mathrm{m}$ ), (ii) densely packed clast fabric, and (iii) dissolution pores (black). Crossed nicols. F. 'Fuchsegg conglomerate' (cf. Fig. 4A) of well-rounded clasts of carbonate rocks and, subordinately, of metamorphic rocks. 'Ga': garnet amphibolite. Inset: Toppled block of conglomerate, showing well-sorted strata. Pen is $14 \mathrm{~cm}$ long.

Abb. 8: A. Grenze (Punkte) zwischen prä-LGM Till und Peerhof-Konglomerat (PC) (Punkt 5 in Abb. 4A). Stift: $14 \mathrm{~cm}$. B. Peerhof-Konglomerat etwa $70 \mathrm{~m}$ im Schichtfallen von Punkt 5 (vgl. Abb 4A). Die sehr dicken Bänke zeigen intern undeutliche Schichtung (gestrichelte Linie) durch parallele Anordnung der Klasten. ,Ga': Granatamphibolit. Stift: 14 cm. C. Peerhof-Konglomerat vom selben Ort wie Abb. 8B. Unterer und oberer Bildteil: sehr schlecht sortierte Feinbis Grobkies-Konglomerate. Mittlerer Bildteil: Lage aus mässig gut sortiertem Mittel- bis Grobkies-Konglomerat (Matrix: lithischer Arenit, überlagert von Linse mit matrixlosem Klastengefüge. D. Dünnschliff des Peerhof-Konglomerats von der Typlokalität (Punkt 2 in Abb. 4A). Beachte: (i) Zusammensetzung aus subgerundeten bis gut gerundeten Klasten von Karbonatgesteinen (meist Wettersteinkalk) und einigen wenigen Metamorphiten (m), (ii) das dichtgepackte Gefüge, und (iii) Lösungsporen (schwarz). Gekreuzte Nicols. E. Dünnschliff des Peerhof-Konglomerats aus einem Aufschluss auf 725 m ü.d.M., 120 
m NW von Punkt 4 (cf. Abb. 4A). Beachte: (i) Zusammensetzung aus subgerundeten Klasten von Karbonatgesteinen (meist Wettersteinkalk) und einigen Metamorphiten (zwei mit m markiert), (ii) das dichtgepackte Gefüge, und (iii) Lösungsporen (schwarz). Gekreuzte Nicols. F. ,Fuchsegg-Konglomerat‘ (vgl. Abb. 4A) aus gut gerundeten Klasten von Karbonatgesteinen und Metamorphiten. ,Ga : Granatamphibolit. Kleinbild: Block des Konglomerats, zeigt Schichten von gut sortiertem Kies. Stift: $14 \mathrm{~cm}$.

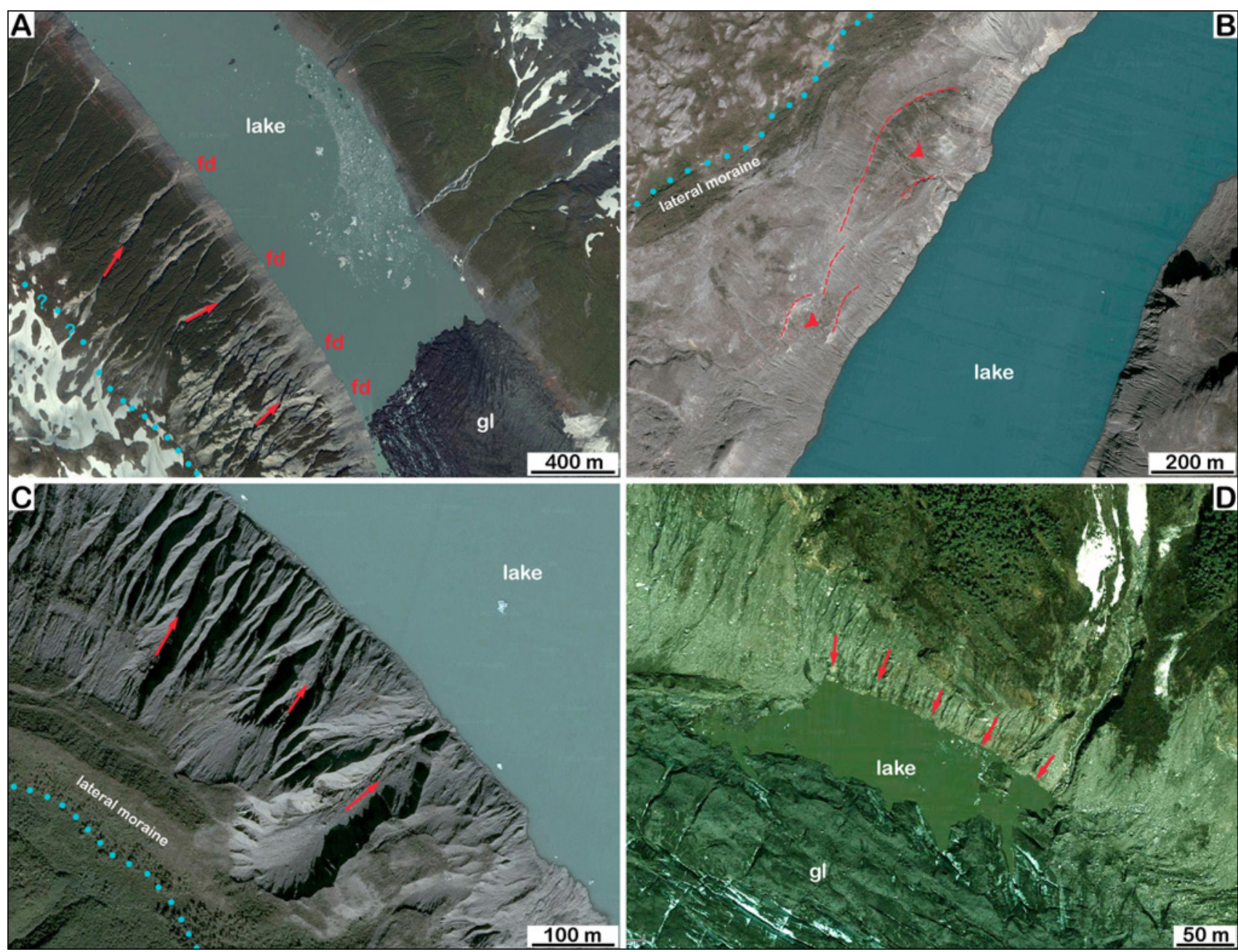

Fig. 9: Satellite images of lakes associated with melting glaciers, Alaska and Northwest Territories. From the margins (blue dots) of formerly larger glaciers, paraglacial redeposition of till into lakes takes place. Till redeposition is mediated by: torrential chutes supplying small fan deltas (fd) (subfigure A), gravitational mass-wasting superposed with erosional ravines (subfigure B), erosional ravines by-passing sediment directly to the subaqueous slope (subfigure C), or redeposition into a small ice-marginal lakes (subfigure D). Due to very short transport routes, the clast spectrum of the redeposited till corresponds to that of the glacial till. Source of images: Google Maps ${ }^{\circledR}$ (download August 15 ${ }^{\text {th }}$,2014).

Abb. 9. Satellitenbilder von Seen an schmelzenden Gletschern, Alaska und Northwest Territories. Von den Rändern (blaue Punkte) vormals grösserer Gletscher kommt es zur paraglazialen Umlagerung von Till, durch: Ephemeral aktive Abflussrinnen, die kleine Fächerdelten (fd) beschicken (Teil-Abbildung A); gravitative Massenbewegungen (rote Pfeilspitzen), die mit Erosionsrinnen überlagert sind (Teil-Abbildung B); Erosionsrinnen, an deren Mündung direkter Eintrag zum subaquatischen Hang stattfindet (Teil-Abbildung C); und Umlagerung von Till in kleine Eisrandseen (Teil-Abbildung D). Wegen der sehr kurzen Transportwege entspricht das Klastenspektrum des umgelagerten Tills dem der Gletschermoräne. Bildnachweis: Google Maps® (download 15. August 2014).

very gently south-dipping stratification are closely similar to the main exposures of Red Breccia farther east (cf. Fig. 1). This implies that during deposition of the HB, alluvial fans reached out westward beyond and downslope of that present westernmost exposure. Along Höttinger Graben, the lowest exposures of Red Breccia between 640-700 $\mathrm{m}$ a.s.l. consistently indicate deposition from subaerial debris flows and ephemeral surface runoff on a subaerial alluvial fan (Fig. 3B) (Penck 1921, Katschthaler 1930, SAlvemini 2013). As shown in Figure 10, because the lower part of the Red Breccia overlaps in altitude with the PC, this reveals a sedimentological contrast: subaqueous deposition (= PC) would co-exist in strike with subaerial deposition along the same altitude.
Already BlAAs (1885, p. 51) noted that the Peerhof deposit is a conglomerate that, relative to the Hötting Breccia farther west, contains many more clasts of metamorphic rocks. PENCK (1921, p. 86) also conceded that the PC differs from the rest of the Hötting Breccia, and designated the conglomerates as delta-like. The inclined stratification of the PC reminded PeNCK (1921, p. 86) of White Breccia with similarly dipping strata at the exit of Mühlau gorge near the eastern limit of the HB (see Fig. 1); the dipping stratal packages at the gorge exit, however, are structurally tilted (D. S., unpubl. data).

As discussed, the PC may have accumulated during decay of the ice stream that deposited its directly underlying till. During deposition of the Red Hötting Breccia, in turn, 


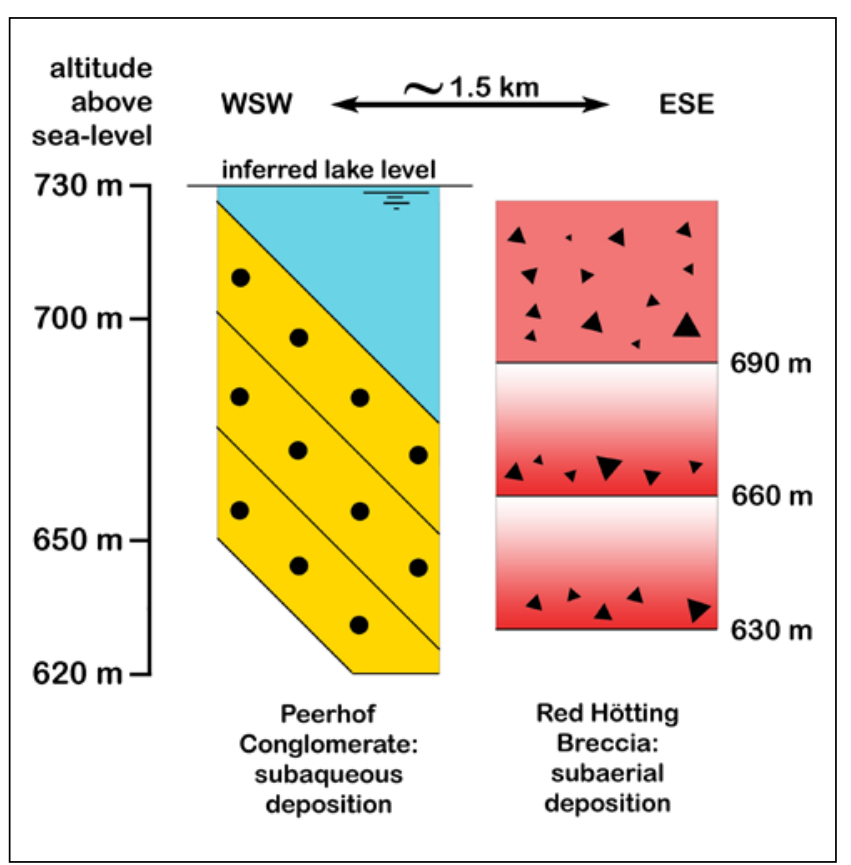

Fig. 10: Overlap in altitude of PC (left column) with the subaerial Red Hötting Breccia $\sim 1.5 \mathrm{~km}$ farther toward ENE (right column) (compare also Fig. 3B). The former lake level at $730 \mathrm{~m}$ a.s.l. is a minimum assumption derived from the outcrops from Peerhof to Allerheiligen.

Abb. 10: Überschneidung der Höhenlage des Peerhof-Konglomerats (limke Säule) mit der subaerischen Roten Höttinger Brekzie etwa 1,5 km weiter gegen ONO (rechte Säule) (vgl. auch Abb. 3B). Der frühere Seespiegel bei 730 m ü.d.M. ist eine Mindestannahme, die aus den Aufschlüssen zwischen Peerhof und Allerheiligen abgeleitet wurde.

the valley floor and at least the lower part of the mountain flanks were vegetated (see section 2 Setting). To preserve an assumption of strictly contemporaneous deposition of $\mathrm{HB}$ and $\mathrm{PC}$, one could assume a cross-valley sediment dam precisely in the area where neither $\mathrm{HB}$ nor PC are preserved (cf. Fig. 3B). This dam had to stand high in order to enable subaerial fan deposition and subaqueous deposition at the same time and same altitude. This hypothesis is discarded as improbable. The simplest scenario is that the PC formed from shedding of reworked till into a lake, or an ice-marginal lake, independent of deposition of the Red Hötting Breccia.

Because of the lateral separation of Red Breccia from the till/PC package, their relative chronostratigraphic position remains unclear. With the present methods of numerical dating, it is hardly possible to derive a depositional age of the PC. Because of their position closely underneath of clear-cut LGM deposits, the till/conglomerate package perhaps represents a vestige of the Riss glacial and its deglacial or interglacial aftermath. In any case, our results indicate that what was previously summarized under the label Hötting Breccia in fact comprises different sediment bodies of different origins and ages.

\section{Acknowledgements}

Karl Krainer, Institute of Geology, University of Innsbruck, is thanked for hinting at the 'forgotten' conglomerates at Peerhof that motivated the mapping of the Quaternary in that area. Karl Krainer and Christoph Spötl provided detailed reviews of a first draft of the manuscript. Peter Tropper, Institute of Mineralogy, University of Innsbruck, provided expertise in assessing thin sections of metamorphic rocks. Alfred Gruber, Geological Survey of Austria, is thanked for literature and discussions. The comments of two anonymous reviewers helped to shorten and to clarify the paper. Samuel Barrett, Institute of Geology, University of Innsbruck, is thanked for correcting the English.

\section{References}

Aber, J. S. \& Ber, A. (2007): Glaciotectonism. - Developments in Quaternary Science, 6: 246 pp.; Amsterdam (Elsevier).

Adamoli, L., Calamita, F. \& Pizzi, A., et al. (2010): Note illustrative della Carta geologica d'Italia alla scala 1:50.000, foglio 349 Gran Sasso d'Italia. - 255 pp.; Roma (Servizio Geologico d'Italia).

Ampferer, O. (1903): Die Mündung des Vomperbaches. - Verhandlungen der kaiserlich-königlichen Geologischen Reichsanstalt, 1903: 231-234.

AMPFERER, O. (1904): Studien über die Inntalterrassen. - Jahrbuch der kaiserlich-königlichen Geologischen Reichsanstalt, 54: 91-160.

Ampferer, O. (1908): Über die Entstehung der Inntalterrassen. - Verhandlungen der kaiserlich-königlichen Geologischen Reichsanstalt, 1908: 87-97.

Ampferer, O. (1914): Über die Aufschliessung der Liegendmoräne unter der Höttinger Brekzie im östl. Weiherburggraben bei Innsbruck. Zeitschrift für Gletscherkunde, 8: 145-159.

AMPfERER, O. (1915): Beiträge zur Glazialgeologie des Oberinntals. Jahrbuch der kaiserlich-königlichen Geologischen Reichsanstalt, 65: 289-316.

Ampferer, O. (1936): Beiträge zur Geologie der Hungerburgterrasse bei Innsbruck. - Jahrbuch der Geologischen Bundesanstalt, 86: 353-358.

AMPFERER, O. (1946): Geologische Ergebnisse von Schutzstollenbauten bei Innsbruck. - Sitzungsberichte der Akademie der Wissenschaften in Wien, mathematisch-naturwissenschaftliche Klasse, Abteilung I, 155: 49-62.

Ballantyne, C. K. (2002): A general model of paraglacial landscape response. - The Holocene, 12: 371-376.

Ballantyne, C. K. \& Benn, D. I. (1994): Paraglacial slope adjustment and resedimentation following recent glacier retreat, Fabergstolsdalen, Norway. - Arctic and Alpine Research, 26: 255-269.

BLAAs, J. (1885): Ueber die Glazialformation im Inntale. - Zeitschrift des Ferdinandeums für Tirol und Vorarlberg, III. Folge, 29. Heft: 1-120.

BLAAs, J. (1889): Ueber sogenannte interglaciale Profile. - Jahrbuch der kaiserlich-königlichen Geologischen Reichsanstalt, 39: 477-482.

BLAAs, J. (1891): Erläuterungen zur geologischen Karte der diluvialen Ablagerungen in der Umgebung von Innsbruck. - Jahrbuch der kaiserlich-königlichen Geologischen Reichsanstalt, 40: 21-50

Böнm, A. (1884): Die Höttinger Breccie und ihre Beziehung zu den GlacialAblagerungen. - Jahrbuch der kaiserlich-königlichen Geologischen Reichsanstalt, 34: 147-162.

Boulton, G. S., Dobbie, K. E. \& Zatsepin, S. (2001): Sediment deformation beneath glaciers and its coupling to the subglacial hydraulic system. - Quaternary International, 86: 3-28.

BÜDEL, J. (1982): Climatic Geomorphology. - 443 pp.; Princeton (Princeton University Press)

Centamore, E., Crescenti, U. \& Dramis, F., et al. (2006): Note illustrative della Carta geologica d'Italia alla scala 1:50.000, foglio 368 Avezzano. - 128 pp., Roma (Servizio Geologico d'Italia).

ChANG, K. H. (1975): Unconformity-bounded stratigraphic units. - Geological Society of America Bulletin, 86: 1544-1552.

Church, M. \& Ryder, J. M. (1972): Paraglacial sedimentation: a consideration of fluvial processes conditioned by glaciation. - Geological Society of America Bulletin, 83: 3059-3071.

Curry, A. M., Cleasby, V. \& Zukowskyj, P. (2006): Paraglacial response of steep, sediment-mantled slopes to post-'Little Ice Age' glacier recession in the central Swiss Alps. - Journal of Quaternary Science, 21: 211-225. DOI:10.1002/jqs.954

Dreimanis, A. (1993): Small to medium-sized glacitectonic structures in till and in its substratum and their comparison with mass movement structures. - Quaternary International, 18: 69-79.

Fliri, F., Bortenschlager, S., Felber, H., Heissel, W., Hilscher, H. \& Resch, W. (1970): Der Bänderton von Baumkirchen (Inntal, Tirol). Eine neue Schlüsselstelle zur Kenntnis der Würm-Vereisung der Alpen. - Zeitschrift für Gletscherkunde und Glazialgeologie, 6: 5-35. 
Gutiérrez, M., Gutiérrez, F. \& Desir, G. (2006): Considerations on the chronological and causal relationships between talus flatirons and palaeoclimatic changes in central and northeastern Spain. - Geomorphology, 73: 50-63.

HaAs, U., Ostermann, M., Sanders, D. ש Hornung, T. (2014): Quaternary sediments in the Werdenfels region (Bavaria, southern Germany). - In: Kerschner, H., Krainer, K. \& SpÖtr, C. (eds.): From the foreland to the Central Alps. Field trips to selected sites of Quaternary research in the Tyrolean and Bavarian Alps. - DEUQUA excursions, pp. 18-30; Berlin (Geozon). DOI:10.3285/g.00011

Hart, J. K., Rose, K. C. \& Martinez, K. (2011): Subglacial till behaviour derived from in situ wireless multi-sensor subglacial probes: Rheology, hydro-mechanical interactions and till formation. - Quaternary Science Reviews, 30: 234-247.

Heissel, W. (1954): Beiträge zur Quartärgeologie des Inntals. - Jahrbuch der Geologischen Bundesanstalt, 97: 251-322.

Hoffmann, K. \& Piotrowski, J.A. (2001): Till mélange at Amsdorf, central Germany: sediment erosion, transport and deposition in a complex, soft-bedded subglacial system. - Sedimentary Geology, 140: 215-234.

Johnson, P. G. (1984): Paraglacial conditions of instability and mass movement. A discussion. - Zeitschrift für Geomorphologie, Neue Folge, 28: $235-250$.

Katschthaler, H. (1930): Neue Beobachtungen im Gelände der Höttinger Brekzie. - Jahrbuch der geologischen Bundesanstalt, 80: 17-44.

KLACKL, D. (2015): Kristallinklasten-Spektrum im Fächerdelta von Vomp (Unterinntal, Tirol). - B. S. thesis, Univ. of Innsbruck, 26 pp.

Koons, D. (1955): Cliff retreat rates in the southwestern United States. American Journal of Science, 253: 44-52.

Kravogl, H. (1873): Zusammensetzung und Lagerung des Diluviums um Innsbruck. - Berichte des Naturwissenschaftlich-Medizinischen Vereins in Innsbruck, 3: 74-86.

LADURNER, J. (1956): Mineralführung und Korngrößen von Sanden (Höttinger Breccie und Umgebung). - Tschermaks Mineralogisch-Petrographische Mitteilungen, 5: 102-109.

LEPsiUs, R. (1913): Die Höttinger Breccie. - Naturwissenschaften, 1: 11221127.

MANDL, G. W. (2000): The Alpine sector of the Tethyan shelf - Example of Triassic to Jurassic sedimentation and deformation from the Northern Calcareous Alps. - Mitteilungen der Österreichischen Geologischen Gesellschaft, 92: 61-77.

MENZIES, J. (2012): Strain pathways, till internal architecture and microstructures - perspectives on a general kinematic model - a 'blueprint' for till development. - Quaternary Science Reviews, 50: 105-124.

Murr, J. (1926): Neue Übersicht über die fossile Flora der Höttinger Breccie. - Jahrbuch der Geologischen Bundesanstalt, 76: 153-170.

Mutschlechner, G. (1948): Spuren des Inngletschers im Bereich des Karwendelgebirges. - Jahrbuch der Geologischen Bundesanstalt, 3-4: 155-206.

Овојеs, U. (2003): Quartärgeologische Untersuchungen an den Hängen der Innsbrucker Nordkette (Höttinger Breccie). - Diploma thesis, Universität Innsbruck.

PAschinger, H. (1950): Morphologische Ergebnisse einer Analyse der Höttinger Brekzie bei Innsbruck. - Schlern-Schriften, 75: 7-86.

Pasquaré, G., Abbate, E., Castiglioni, G., Merenda, B., Mutti, E., Orombelli, G., Ortolani, F., Parotto, M., Pignone, R., Polino, R., Premoli-Silva, I. \& SAssi, F. P. (1992): Carta Geologica d'Italia alla scala 1:50.000. Guida al rilevamento. - 203 pp., Roma (Servizio Geologico d'Italia).

Penck, A. (1882): Die Vergletscherung der deutschen Alpen: ihre Ursachen, periodische Wiederkehr und ihr Einfluß auf die Bodengestaltung. - 483 pp.; Leipzig (Barth).

Penck, A. (1885): Ueber interglaziale Breccien der Alpen. - Verhandlungen der kaiserlich-königlichen Geologischen Reichsanstalt, 1885: 363-366.

Penck, A. (1887): Die Höttinger Breccie. - Verhandlungen der kaiserlichköniglichen Reichsanstalt, 1887: 140-145.

Pernreiter, S. (2014): Das Quartär in der Kiesgrube Allerheiligen und deren näherer Umgebung. - B.S. thesis, Univ. of Innsbruck, 44 pp.
Piller, W. E., Egger, H. \& Erhart, C. W., et al. (2004): Die stratigraphische Tabelle von Österreich 2004 (sedimentäre Schichtfolgen). Wolkersdorf (Gerin print).

Ravazzi, C., Badino, F., Marsetti, D., Patera, G. \& Reimer, P. J. (2012) Glacial to paraglacial history and forest recovery in the Oglio glacier system (Italian Alps) between 26 and $15 \mathrm{ka} \mathrm{cal} \mathrm{BP.} \mathrm{-} \mathrm{Quaternary} \mathrm{Sci-}$ ence Reviews, 58: 146-161.

ReItner, J. M. (2007): Glacial dynamics at the beginning of Termination I in the Eastern Alps and their stratigraphic implications. - Quaternary International, 164-165: 64-84.

REITNER, J. (2011): Das Inngletschersystem während des Würm-Glazials. - In: Gruber, A. (ed.), Arbeitstagung 2011 der Geologischen Bundesanstalt, Blatt 88 Achenkirch. Geologische Bundesanstalt, Vienna, pp. $79-88$

RüMmele, F. (2015): Das Klastenspektrum am Ausgang des Silltals be Innsbruck. - B. S. thesis, University of Innsbruck.

RuszcZYNSKA-SzENAJCH, H. (2001): “Lodgement till' and "deformation till." - Quaternary Science Reviews, 20: 579-581.

Salvemini, S. (2013): Die Höttinger Breccie beim geplanten Rückhaltedamm Höttinger Graben. - B. S. thesis, Univ. of Innsbruck, 44 pp.

SANDERS, D. (2008): Eislast-Erscheinungen und Intraklasten in der Höttinger Brekzie (Riß-Würm Interglazial) bei Innsbruck (Österreich). Geo.Alp, 5: 149-164.

SANDERS, D. (2010): Sedimentary facies and progradational style of a Pleistocene talus-slope succession, Northern Calcareous Alps, Austria. Sedimentary Geology, 228: 271-283. DOI:10.1016/j.sedgeo.2010.05.002

SANDERS, D. (2012): Effects of deglacial sedimentation pulse, followed by incision: A case study from a catchment in the Northern Calcareous Alps (Austria). - E\&G Quaternary Science Journal, 61: 16-31. DOI:10.3285/eg.61.1.02

SANDERs, D. \& Ostermann, M. (2006): Depositional setting of the sedimentary rocks containing the "warm-interglacial" fossil flora of the Höttinger Brekzie (Pleistocene, Northern Calcareous Alps, Austria): a reconstruction. - Veröffentlichungen des Tiroler Landesmuseums Ferdinandeum, 86: 91-118.

SANDERs, D. \& Ostermann, M. (2011): Post-last glacial alluvial fan and talus slope associations (Northern Calcareous Alps, Austria): A proxy for Late Pleistocene to Holocene climate change. - Geomorphology, 131: 85-97. DOI:10.1016/j.geomorph.2011.04.029

SAnders, D. \& Spötl, C. (2014): The Hötting Breccia - a Pleistocene key site near Innsbruck, Tyrol. - In: Kerschner, H., KrAINER, K. \& SPÖTL C. (eds.), From the foreland to the Central Alps. Field trips to selected sites of Quaternary research in the Tyrolean and Bavarian Alps. Geozon Science Media, Berlin, pp. 82-94. DOI: 10.3285/g.00011

SAnders, D., Ostermann, M. \& Kramers, J. (2009): Quaternary carbonate-rocky talus slope successions (Eastern Alps, Austria): sedimentary facies and facies architecture. - Facies, 55: 345-373. DOI:10.1007/ s10347-008-0175-Z

SAnders, D., Ostermann, M. $\mho$ Kramers, J. (2010): Meteoric diagenesis of Quaternary carbonate-rocky talus slope successions (Northern Calcareous Alps, Austria). - Facies, 56: 27-46. DOI:10.1007/s10347-0090194-4.

Siegl, G. \& FAHLEnBöcK, M. (2012): Geschichtliches zur Höttinger Brekzie. - In: Siegl, G. \& UnTerwurzacher, M. (eds.), Die Höttinger Brekzie - ein Tiroler Werkstein. Entstehung, Abbauorte, Geschichte, Verwendung, Erhaltung. Innsbruck University Press: 35-45, Innsbruck (Universität Innsbruck)

Spötl, C., MANGini, A. \& Cheng, H. (2014): Radiometric constraints on the age of the Hötting Breccia (Innsbruck, Austria). - Zeitschrift für Gletscherkunde und Glazialgeologie, 47/48: 135-146.

Van Husen, D. (2000): Geological Processes during the Quaternary. - Mitteilungen der Österreichischen Geologischen Gesellschaft, 92: 135-156.

WeHrLI, H. (1928): Monographie der interglazialen Ablagerungen im Bereich der nördlichen Ostalpen zwischen Rhein und Salzach. - Jahrbuch der Geologischen Bundesanstalt, 78: 357-495.

Wettstein, R. v. (1892): Die fossile Flora der Höttinger Breccie. - Denkschriften der kaiserlichen Akademie der Wissenschaften in Wien, mathematisch-naturwissenschaftliche Classe, 59: 479-524. 